Portland State University

PDXScholar

Summer 8-3-2015

\title{
An Examination of Factors that Catalyze LGBTQ Movements in Middle Eastern and North African Authoritarian Regimes
}

Michael Anthony Figueredo

Portland State University

Follow this and additional works at: https://pdxscholar.library.pdx.edu/open_access_etds

Part of the African Studies Commons, Lesbian, Gay, Bisexual, and Transgender Studies Commons, Near and Middle Eastern Studies Commons, and the Political Science Commons Let us know how access to this document benefits you.

\section{Recommended Citation}

Figueredo, Michael Anthony, "An Examination of Factors that Catalyze LGBTQ Movements in Middle Eastern and North African Authoritarian Regimes" (2015). Dissertations and Theses. Paper 2478. https://doi.org/10.15760/etd.2475

This Thesis is brought to you for free and open access. It has been accepted for inclusion in Dissertations and Theses by an authorized administrator of PDXScholar. Please contact us if we can make this document more accessible: pdxscholar@pdx.edu. 
An Examination of Factors that Catalyze LGBTQ Movements in Middle Eastern and North African Authoritarian Regimes

by

Michael Anthony Figueredo

A thesis submitted in partial fulfillment of the requirements for the degree of

\author{
Master of Science \\ in \\ Political Science
}

Thesis Committee:

Lindsay Benstead, Chair

Melody Valdini

David Kinsella

Portland State University

2015 
(C) 2015 Michael Anthony Figueredo 


\begin{abstract}
Citizens' increased access to the internet is transforming political landscapes across the globe. The implications for civil society, culture, religion, governmental legitimacy and accountability are vast. In nations where one does not typically expect "modern" or egalitarian ideals to be prevalent among highly religious and conservative populations, those with motivations to unite around socially and culturally taboo causes are no longer forced to silently acquiesce and accept the status quo. The internet has proven to be an invaluable tool for those aiming to engage in social activism, as it allows citizens in highly oppressive authoritarian regimes to covertly mobilize and coordinate online protest events (such as hashtag campaigns, proclamations via social media, signing of petitions, and even DDoS attacks) without the fear of repression.

What catalyzes lesbian, gay, bisexual, transgender, and queer/questioning (LGBTQ) equality movements in authoritarian regimes, specifically with respect to the Middle East and North African region? This thesis argues that gay rights movements are more likely to emerge in politically repressive, more conservative states when new political opportunities - namely access to the internet for purposes of political organization—become available. This master's thesis identifies why LGBTQ movements emerged in Morocco and Algeria, but not in Tunisia until after it underwent democratization. These states will be analyzed in order to gauge the strength of their LGBTQ rights movements and, most importantly, to identify which variables most cogently explain their existence altogether.
\end{abstract}


Dedication

I dedicate this thesis to all the members of my family and extended family, namely my parents, Charles and Bernadette Figueredo, along with Jim and Carie Shields —and most of all — to Robert Shields. I am also thankful to my siblings: Lindie, Lisa, Charles Jr., and Mark (as well as their partners; Jeff, Shannon, Pauline, and Tia) for their ongoing encouragement. This thesis is also dedicated to my nieces and nephews: Miranda, Meagan, Marissa, Kaleb, Isaac, Christian, Angel, Taylor, Taryn, Kyra, Americus, Charles Jr. III, and my great nephew, Ellye. Lastly, I want to dedicate this thesis to my good friends Jessie and Chelsea. Without the support and encouragement from all of these people, the pursuance of my academic goals would have been seemingly more daunting. 
Acknowledgments

I am very thankful and privileged to have had the opportunity to work with the faculty at Portland State University’s Mark O. Hatfield School of Government. I am particularly appreciative of Dr. Lindsay Benstead and Dr. Melodi Valdini for acting as my mentors and assisting me throughout the course of my thesis' development. I am also grateful to Dr. Albert Spencer III primarily for being an influential figure to me during my time as an undergraduate. Furthermore I want to thank the members of my thesis committee, Dr. David Kinsella along with Dr. Benstead and Dr. Valdini again for their willingness to participate in the defense of this thesis. All of my professors have been instrumental in both my personal development and academic success throughout my tenure as a graduate student and I am very grateful to them for that. 
Table of Contents

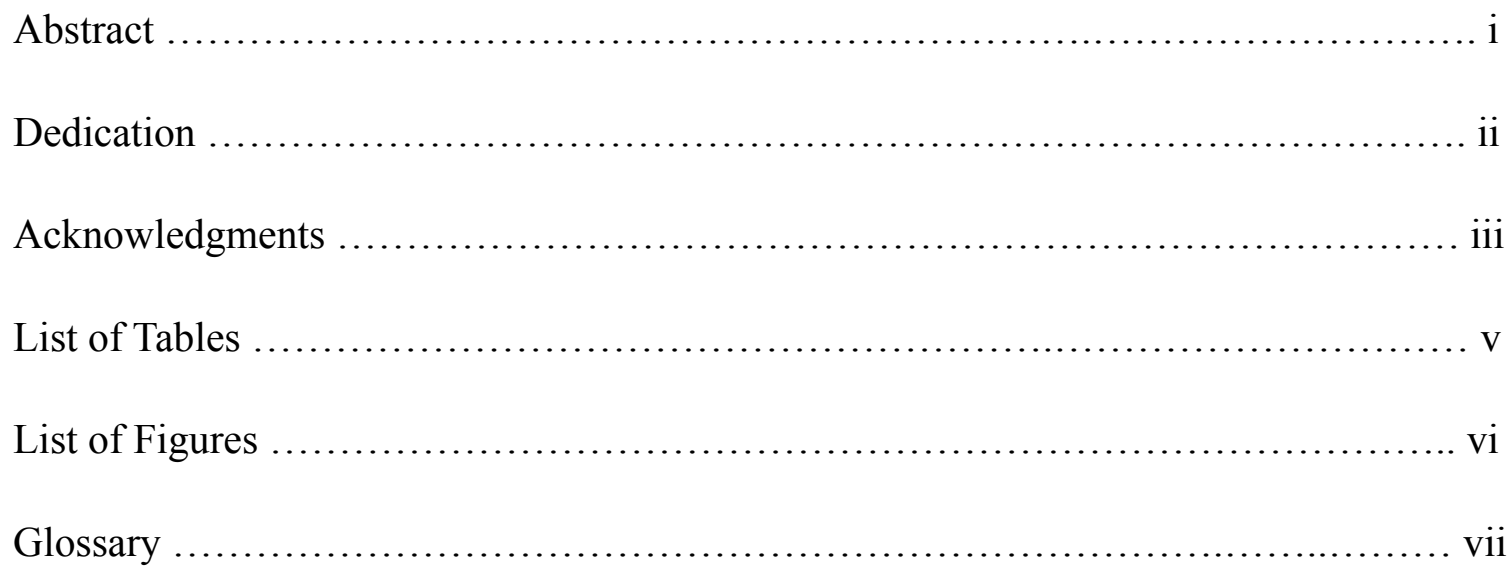

Chapter 1

The Emergence of LGBTQ Movements in the MENA $\ldots \ldots \ldots \ldots \ldots \ldots \ldots \ldots \ldots \ldots \ldots \ldots$

Chapter 2

The Social Status of Sexual \& Gender Minorities $\ldots \ldots \ldots \ldots \ldots \ldots \ldots \ldots \ldots \ldots \ldots \ldots \ldots \ldots$

Chapter 3

Profiling the Strength of LGBTQ Movements in Morocco, Algeria, \& Tunisia ......... 34

Chapter 4

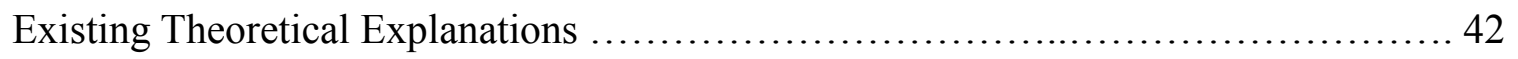

Chapter 5

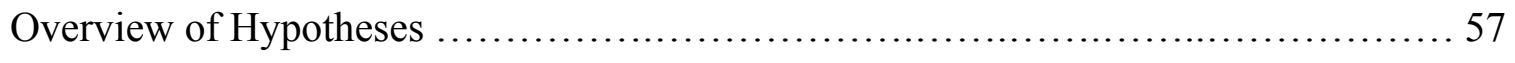

Chapter 6

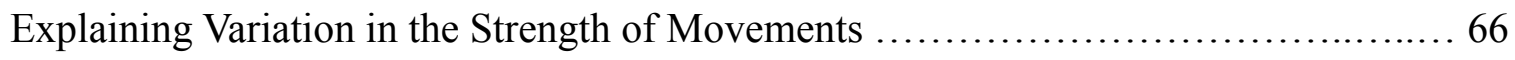

Chapter 7

Conclusion \& Implications for Social Movement Research ........................ 94

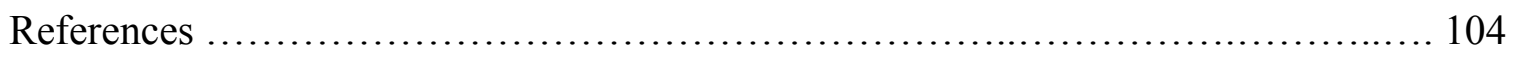


List of Tables

Table 1.1: Postmaterialist Values in the MENA Region ............................. 6

Table 1.2: Four Tiers of Online Activism in Authoritarian Regimes .................. 16

Table 2.1: The Legality of Homosexuality in the Middle East and North Africa ........ 19

Table 5.1: Internet Penetration in the Middle East and North Africa .................... 61 
List of Figures

Figure 3.1: Strength of LGBTQ Movements in Morocco, Algeria, \& Tunisia .......... 41

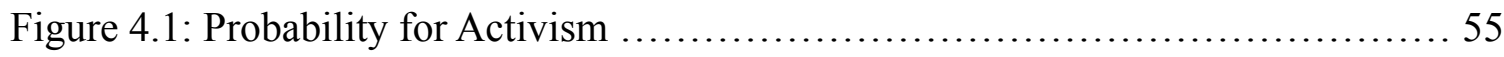

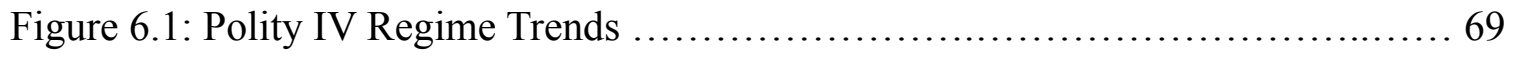

Figure 6.2: Freedom House Trends ...................................... 70

Figure 6.3: Internet Penetration Rate (IPR) Growth ........................... 75

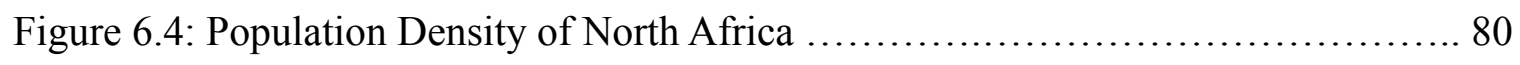

Figure 6.5: Illustration of Movement Strength Crossed by Internet Trends ........... 83 
Cisgender - Is an individual whose birth sex correlates with their prescribed gender. In essence it is an individual that does not identify as transgender or agender.

Coming Out - The process by which an individual publicly reveals a fundamental component of their identity (e.g. sexual, gender, religious, secular, feminist, etc.).

Gay Community - Though this has homosexual connotations, it is typically used as an umbrella term that is inclusive of the collective LGBTQ community, including transgender individuals, asexual individuals, pansexuals, intersex persons, and even straight allies.

Gender - Is different from sex in that sex refers to one's physiological composition, whereas gender is typically the expression of masculine, feminine, or neither of those two characteristics. Descriptively, men usually choose to express their gender by being masculine while women express it by being more feminine. Though this may be a prevalent cultural norm, it is purely stereotypical. Many individuals deviate from these traditional gender roles, hence the need for descriptive terms such as "tom boy," for example.

Gender Identity - Refers to how individuals express their gender or label themselves.

Gender Minority - Is an individual or group of individuals that are not cisgender; that is, their birth sex does not match their gender (see Transgender definition).

Intersectionality - Is when one person has multiple identities. For example, an individual may be a member of multiple communities (e.g. gay woman of color, 
straight cisgender secular man, or Islamic feminist). The labels most individuals identify with are not mutually exclusive.

LGBTQ - An acronym referring to the aggregate community of sexual and gender minorities; lesbian, gay, bisexual, transgender, and queer/questioning individuals. Several variants are possible such as 'LGBTI' or 'LGBTP' to include intersex and pansexual individuals.

MENA - Is an acronym that refers to states within the Middle East and North African region. It is also commonly referred to as the "Arab world."

Non-Binary Gender Identity - Is a gender identity that is not associated with the male or female sex. A non-binary gender identity may incorporate characteristics from both the male and female genders or may deviate from both entirely. It is a gender identity that is more flexible and not subject to normative preconceptions of the binary gender system.

Sexual Minority - Is an individual that is attracted to the same sex or gender, is not attracted to binary genders, or does not have a sexual orientation altogether.

Transgender - A person that identifies as a gender not correlated with their birth sex. 
Chapter 1

The Emergence of LGBTQ Movements in the MENA

Regimes in the Middle East and North Africa (MENA) have dismal reputations internationally for authoritarianism and lack of political reform. Overt corruption, restrictions on civil liberties, and gross violations of human rights are commonplace in the region. These aspects of authoritarian governance are merely a snapshot of an exhaustive catalog of problems that hinder regional peace and stability, as societal issues such as sectarian violence, political cleavages, terrorism, and widespread religious fundamentalism also contributes to much of the turmoil that plagues these states. Despite the dismal political context, citizens in MENA countries appear remarkably happy. The World Values Survey (2010-2014, V10) illustrates that an average of $23.9 \%$ of respondents in the region claim to be "very happy" and an average of 52.9\% - a majority —assert they are "rather happy" (compared to $36.1 \%$ and $53.5 \%$ in the United States, respectively). ${ }^{1}$ The level of happiness of a populace is a good indication that citizens do not feel their political situation is hopeless. Citizens in the MENA region are becoming

\footnotetext{
${ }^{1}$ States and territories included in this study are Algeria, Bahrain, Cyprus, Palestine, Iraq, Jordan, Kuwait, Lebanon, Libya, Morocco, Qatar, Tunisia, Egypt, Yemen, and for comparative reasons, the United States (see World Values Survey 2010-2014, V10).
} 
increasingly politically active even under heavily repressive regimes that attempt to violently stifle demonstrations.

In 2011 citizens in the MENA, from the Sahrawi people in the Western Sahara to the citizens of Saudi Arabia, mobilized in protests. Though some regimes—primarily monarchical ones - proved to be quite resilient, the Arab spring lead to the overthrow of several autocratic dictators: Zine El Abidine Ben Ali in Tunisia, Muammar Gaddafi in Libya, and Hosni Mubarak in Egypt. What once seemed unfathomable had finally occurred. These events raise questions about what catalyzed unprecedented social mobilization. Many political scientists contend that technological growth, specifically higher levels of internet penetration, the proliferation of smartphones, and increased access to satellite television channels such as Al Jazeera has fostered conditions that allowed the Arab spring to occur (Lust 2013; Lynch 2012; Hussain \& Howard 2013). Lust argues that the internet was a key tool for political mobilization $(2013,283)$. The internet could also trigger a plethora of political consequences, including the emergence of movements for socially and culturally taboo causes that would not otherwise exist without it.

One of the potential upshots of greater access to the internet is the materialization of lesbian, gay, bisexual, transgender, and queer/questioning (LGBTQ) equality movements throughout the region within the last decade. The strength and overall existence of these movements, however, is not consistent in every state. For example, Morocco and Algeria, two socially conservative and politically repressive states, both 
have sizable gay rights movements, but the Moroccan LGBTQ movement differs in that it is both stronger than Algeria's and has existed longer. In Tunisia, a more socially liberal state, LGBTQ activism was nonexistent until it underwent democratization. Why did members of the LGBTQ community become politically active in two socially conservative authoritarian states (Morocco and Algeria), but not in Tunisia, a more openminded, secular, and socially liberal authoritarian state?

Theoretically, one should expect to find a more robust LGBTQ movement in Tunisia seeing as how social conservatism is less prevalent there. Issues related to gender equality, alcohol consumption, and secularity are much less controversial in Tunisia in comparison with Morocco and Algeria, but in spite of this fact Tunisia is the last of these three states to witness the emergence of a gay rights movement. What factor explains variation in the size, strength, time of arrival, and, most importantly, the overall existence of LGBTQ movements between these three relatively similar states? Solving this puzzle will yield an answer to an even broader question: what catalyzes LGBTQ movements in politically repressive authoritarian regimes in the Middle East and North Africa?

My argument is that the advent of new political opportunities (in this case, expanded internet access and internet freedom) explains why gay rights movements are able to emerge in authoritarian regimes. This argument hinges on my findings from Morocco, Algeria, and Tunisia. Variation in the strength and existence of LGBTQ movements in these three cases can be attributed to varying degrees of access to the internet and internet freedom in each state. The internet is a crucial resource to gay rights 
activists in the MENA, therefore limitations on internet access and internet freedom will inhibit their ability to engage in activism. This claim substantiates the resource mobilization school of thought.

This implies that restraints of dictatorial and oppressive governments may no longer be able to hold back political change. Due to citizens' increased access to the internet, advocates for gay rights and other "postmaterialist" causes are able to forge movements that could potentially gain ascendency in the coming decades now that they have the ability to discretely mobilize and collude with like-minded citizens to anonymously petition their governments for a redress of grievances. However, even with the presence of new political opportunities, this type of activism in the MENA region runs contrary to our current theoretical understandings of social movements and why they emerge in the first place.

\section{The Rise of Postmaterialism in the Middle East \& North Africa}

Many MENA citizens are socioeconomically disadvantaged, therefore one could logically deduce that they will be more inclined to adopt political orientations tailored to their physical (material) well-being as opposed to their social status (postmaterial). To engage in activism for the latter cause would imply its participants hold postmaterialist values. Postmaterialism is defined as a "value orientation that emphasizes self-expression and quality of life over economic and physical security" (Encyclopedia Britannica 2008). The concept of postmaterialism was developed by Inglehart (1977) who postulates that individuals have a hierarchy of values. He states, 
The values of Western publics have been shifting from an overwhelming emphasis on material well-being and physical security toward greater emphasis on the quality of life. [...] People tend to be more concerned with immediate needs or threats than with things that seem remote or nonthreatening. Thus a desire for beauty may be more or less universal, but hungry people are more likely to seek food than aesthetic satisfaction (Ibid 1990, 5).

This indicates states who have not advanced industrially and/or those in which the physical vulnerability of their citizens is high ${ }^{2}$ will be unlikely to foster political environments that are conducive to more "modern" or egalitarian views on matters such as civil rights and social equity.

In theory, values that facilitate the emergence of such causes should not be prevalent — or exist at all—in the MENA region according to existing sociological and political science concepts such as modernization theory, but that is not the case. The mere existence of LGBTQ activism suggests that egalitarian, socially liberal, and modern views are held by some. The World Values Survey (2010-2014, Y002) measures postmaterialism in the MENA region using 4-item inter-related questions in order to gauge values. ${ }^{3}$ It found that a majority of citizens in many MENA states hold mixed material/postmaterialist values, and an average of $5.3 \%$ of citizens mostly embrace postmaterialist values (see Table 1.1). This is not surprising when accounting for the recent surge of LGBTQ activism in the region.

\footnotetext{
2 This is perhaps due to territorial disputes (such as the Arab-Israeli territorial dispute) or high levels of state-sponsored violence or repression in authoritarian regimes.

${ }^{3}$ It should be noted that the methodology for this particular question is not available for this variable, but the World Values Survey is a reputable organization that is cited with regularity in academia. Still, for purposes of this discussion, it would prove beneficial to know how postmaterialism is measured, but the point of bringing this up is merely for illustrative purposes to show that these values do exist in the MENA, albeit to a small degree.
} 
Table 1.1: Postmaterialist Values in the MENA Region

\begin{tabular}{|c|c|c|c|c|c|c|}
\hline Algeria & Bahrain & Cyprus & Palestine & Iraq & Jordan & Lebanon \\
\hline $5.1 \%$ & $20.2 \%$ & $5.8 \%$ & $5.6 \%$ & $3.5 \%$ & $2.6 \%$ & $7.7 \%$ \\
$(44.8 \%)$ & $(60.5 \%)$ & $(51 \%)$ & $(45.8 \%)$ & $(52.4 \%)$ & $(37.8 \%)$ & $(55.2 \%)$ \\
\hline Libya & Morocco & Qatar & Tunisia & Turkey & Egypt & Yemen \\
\hline $4.2 \%$ & $2.9 \%$ & $4.7 \%$ & $.9 \%$ & $10.7 \%$ & $1.1 \%$ & $.9 \%$ \\
$(63 \%)$ & $(42.4 \%)$ & $(53 \%)$ & $(25.6 \%)$ & $(53.3 \%)$ & $(36.6 \%)$ & $(28.9 \%)$ \\
\hline
\end{tabular}

Note: Percentages in parentheses indicate mixed postmaterialist and materialist values. Source: World Values Survey (2010-2014, Y002).

Postmaterialist causes are, in effect, those wherein the primary political objective is to eliminate conditions that diminish the overall quality of living for particular citizens (Ibid). These causes will typically be related to social equality and may include gay and transgender rights, atheist, agnostic, areligious, anti-theist, and deist (AAAAD) ${ }^{4}$ rights, indigenous people's rights, and racial/ethnic minorities' rights movements. These examples do not encompass the totality of possible movements for postmaterialist causes, but instead are part of a broader range of postmaterialist issues. Many individuals assume these types of movements, especially those advocating for LGBTQ rights, do not exist in conservative, autocratic regimes seeing that they are widely regarded as "taboo" or "haram" and are too controversial to attain political clout, but the recent materialization of LGBTQ rights movements in the MENA forces introspection within the social science community since these movements do exist; however, the character of these movements differs from their Western counterparts.

\footnotetext{
${ }^{4}$ While the terms 'atheist' and 'areligious' may sound redundant, they are differentiated by the fact that atheism is the belief that a god does not exist whereas an areligious individual may believe a god exists, but does not subscribe to a particular religion.
} 


\section{Characteristics of Gay Rights Movements in the MENA}

The first, and perhaps most significant, difference between Western gay rights movements and those which exist in the global South is short-term goals. In the West, LGBTQ activists' short term goals may be full marriage equality and federal antidiscrimination legislation to protect their community from employment discrimination and/or societal prejudice. Their long-term goals will be broader and encapsulate full legal and societal equality. Conversely, the goals of gay rights activists in the MENA region may ultimately coincide with Western LGBTQ activists, but they fundamentally differ in one important respect: Western activists possess goals that cannot be feasibly achieved by activists in the MENA. A short-term goal for LGBTQ activists in many MENA countries is the amelioration of governmental persecution. In contrast, a common long-term goal is full legal recognition of one's right to identify as gay, lesbian, bisexual, or transgender and practice homosexuality or express one's gender identity freely.

These groups typically establish goals by coalescing around legal and social matters that are most culpable in the perpetuation of their collective marginalization. Given that the mere act of homosexuality is legally prohibited in most MENA states ${ }^{5}$, decriminalization is a common goal for most gay rights activists in the region. This criteria for goal attainment is comparable for Western activists, but they are not reluctant to demand sweeping reform. This is a luxury that is afforded to them for living in a democracy. These differences are also dependent on the fact that Western activists have

\footnotetext{
${ }^{5}$ See Chapter 2, Table 2.1.
} 
prodigious movements that have persisted for decades, and as a result, they have been able to gain considerable ground in many countries and are now in a position to ask for full recognition of their rights. This is not the case for many movements for postmaterialist causes in the MENA, especially when it comes to the issue of gay rights. LGBTQ equality movements in the MENA are still in the early stages of development; but regardless, their growth has been appreciable.

While Middle Eastern and North African LGBTQ movements have seen an increase in numbers and have become more organized, they have not made much political or social progress. The Western LGBTQ community has been successful in part due to its ability to gain support from heterosexual and cisgender ${ }^{6}$ allies - a tactic very much in line with African American civil rights activists who fought for desegregation in the " 60 s by drawing support from white political allies.

Gay rights movements in the MENA region have diminished standards and lower expectations in comparison to their Western counterparts for the fact that the prospect of legal marriage equality — let alone the prospect of legalizing homosexuality — is currently inconceivable to them. This forces MENA activists to adjust their expectations to match short and long-term goals that are actually feasible. Putnam (1988) discusses the notion of a "win-set," which is a concept from the field of international relations that describes how the preferences of a state's domestic constituents establish the parameters of an international agreement. He writes, "[ $[$ ] $]$ he larger the win-set, the more easily he [the chief

\footnotetext{
${ }^{6}$ Refer to "Cisgender" in the Glossary for the definition of this identity.
} 
negotiator acting on behalf of the state] can conclude an agreement, but also the weaker his bargaining position vis-à-vis the other negotiator" (450). While this view is prominent in the game theory research methodology—which is mostly utilized for analyzing strategic interactions between international entities - the concept of win-sets is useful if we extrapolate it to the interaction between social activists and governments.

One can expect LGBTQ movements in the MENA to have very large win-sets because they will be willing to except any concession from the government in order to improve their social situation even if it is unsatisfactory. Their win-set is large because they lack negotiating power. Groups do not typically shrink their win-sets until they attain political power, which is adjoined to the level of bargaining power they possess. A group with a small win-set will not be appeased by a piece of legislation that, for instance, prohibits discrimination against gays, lesbians, and bisexuals, but not transgender individuals. Their win-set is small because the list of demands they will willingly accept is shorter. In contrast, groups with larger win-sets are easier to appease since they have a large list of policy concessions that will satisfy them since nearly anything will qualify as a win. Contrarily, the government (i.e. their chief opponent) will have a microscopic winset for the fact that MENA governments will forego negotiations altogether as highly disliked and disadvantaged groups do not yet pose a threat to the legitimacy of many authoritarian governments. Seeing as how Western LGBTQ activists have substantial social and political power in the form of lobbying, their respective governments will be more inclined to concede to their demands for the fact that they pose a direct threat to 
state legitimacy. Victory may be unattainable in the foreseeable future for LGBTQ rights activists in the MENA, but this daunting fact has not kept them from trying.

Amidst high costs and a low payoff, there has been a surge in acts of civil disobedience among all types of postmaterialist activists in even the most repressive totalitarian and authoritarian regimes. A Saudi Arabian atheist activist, Raif Badawi, posted an online statement advocating free speech for atheists in spite of the fact that the ensuing penalty for doing so would be severe (Hubbard 2015). Additionally, on the International Day Against Homophobia members of the LGBTQ community in Tehran uploaded photographs of themselves with rainbow flags and signs reading "no to homophobia" to Joopea, a popular social networking website in Iran (Fisher 2012). In Egypt, in an act of protest, eight men uploaded a video to YouTube of themselves attending and taking part in a wedding ceremony between a same-sex couple in Nile (Kingsley 2014). One thing these instances of activism all have in common is that they occur through a proxy: the internet.

Political scientists and sociologists must contemplate whether these occurrences of online activism are merely isolated, insignificant, and spurious or rather, that they are occurring due to the arrival of a new political opportunity that was not previously available. I do not believe these instances of activism are benign. Quite contrarily, I contend that they signify the initiation of new social movements. Identification of the cause(s) of these new movements will be fruitful for future social science research. The type of postmaterialist movement that is most appropriate for an evaluation is LGBTQ 
rights movements for two reasons: (a) they are the most prevalent of all new movements to proliferate in the region, and (b) their persistent growth and longevity ${ }^{7}$ makes them easier to measure.

\section{Research Question \& Forecasting Arguments}

Why do LGBTQ movements emerge in authoritarian regimes in the Middle East and North Africa? This thesis argues that gay rights movements are more likely to emerge in conservative authoritarian regimes when new political opportunities-namely access to the internet for purposes of political organization-become available. In light of the recent emergence of postmaterialist movements in the MENA, this graduate thesis examines LGBTQ movements in three such cases: Morocco, Algeria, and Tunisia. The following chapter details the low social status of the aggregate LGBTQ community in the MENA region. Chapter 3 outlines the strength of LGBTQ movements in Morocco, Algeria, and Tunisia. Chapter 4 provides a literature review of competing theoretical explanations as well as arguments outlining what causes new social movements to arise.

Chapter 5 introduces hypotheses that explain which factor(s) catalyze gay rights activism in authoritarian regimes.

In the sixth chapter I test my hypotheses by utilizing a most similar systems research design (MSSD) methodology with three relatively similar case studies: Morocco, Algeria, and pre/post-revolutionary Tunisia. Both Morocco and Algeria are authoritarian states that have fairly large LGBTQ movements, but a gay rights movement

\footnotetext{
${ }^{7}$ What I mean by longevity is that these movements have not dissipated over time. Instead, they have all grown since materialization and have yet to disband.
} 
did not materialize in Tunisia until it democratized in spite of the fact that it is much more socially liberal in comparison to the two former states mentioned. I argue that variation between the strength and existence of LGBTQ movements in these three states is caused by varying degrees of access to the internet. Moroccans and Algerians had more internet freedom in comparison to Tunisians, hence the reason why gay rights activism did not emerge in Tunisia until after democratization, which is when restrictions on the internet were abolished. I also argue that Morocco's LGBTQ movement is slightly larger than Algeria's despite comparable levels of internet freedom because more Moroccans have access to the internet than Algerians.

Overall, it will be demonstrated that an underlying level of internet freedom is a necessary prerequisite for this type of activism to emerge. The degree to which a vulnerable group is able to bypass internet restrictions to collude with other activists is a significant determinant for a movement's success and existence. If a government is too repressive and aims to stymie any and all types of political activism, a movement may not be able to flourish even if it has adequate access to the internet. This will be detailed more thoroughly in Chapter 7, where I will review the overall findings of this thesis, its applicability to other movements for postmaterialist causes, and implications it has on social movement research.

\section{Rethinking Activism}

Before proceeding it will be necessary to elaborate on what is meant by "online activism" in order to sufficiently make the case that it should be categorized into 
traditional conceptions of activism and social movements. A social movement is a phenomenon whereby citizens with like-minded interests align and engage in contentious politics by confronting “elites, authorities, and opponents" in order to change the legal and social status quo (Tarrow 2011, 6). Mass protests, boycotts, and various types of strikes are typically associated with existing notions of activism, but online activism is becoming equally instrumental to protesters of all stripes. In the MENA region, gay rights activism occurs almost exclusively through the internet, thus making it seemingly amorphous. However, several types of tactics are easily identifiable and have proven to be quite effective to boot. There is a diverse array of methods employed by online activists, ranging from political declarations via social media, signing of online petitions, coordinated "hashtag" campaigns, and even DDoS attacks on government websites. Dismissing this realm of activism is problematic since the internet is the newest frontier for political activism, and as a result, it will allow us to acquire key insight into the emergence of new social movements of the $21^{\text {st }}$ century. For this to be possible, our conceptions of what constitutes social movements must evolve to accommodate it, especially if we are going to measure new types of social movements in authoritarian regimes.

Bayat (2005) calls for "a more fluid and fragmented vision of social movements" by "attempting to present an angle which might help account for complexities" (893). I also hold this view. Though the chief method in which LGBTQ activism occurs in the MENA (via online) is admittedly unorthodox, the dawn of the technological era requires 
us to update our preconceived notions of what constitutes "activism" or a "social movement" because LGBTQ activism in most MENA states - for the time being - is inextricably linked to the internet. ${ }^{8}$ Bayat writes, "Given the fragmented nature of contemporary social movements, $[\ldots]$ a plausible narrative would take account of the heterogenous layers of perceptions, discourses and practices within a given movement" (905). Following this logic, online activism should be incorporated into our discussion of social movements.

Seeing as how the internet is a launching point for gay rights movements in the MENA, it is beneficial to differentiate between different 'tiers' of activism and hierarchically arrange these movements by size and type before proceeding. Categorization of online activism into different tiers is necessary in order to distinguish between varying levels of strength in movements and also to account for various forms of online political protests that become more coordinated and complex as movements grow. Online activism should be mapped onto a spectrum and cannot be arbitrarily dichotomized. In total there are four tiers that outline and define the parameters of activism that take place under authoritarian regimes on the internet (see Table 1.2). As the size and strength of these movements grow they will advance to the next subsequent tier.

States that encompass the lowest level of online activism (titled 'Tier 1') contains minimal amounts of isolated incidents of civil disobedience and instances of activism that are typically sporadic and not necessarily catalyzed by a particular causal mechanism.

\footnotetext{
${ }^{8}$ This will be addressed in the following chapters.
} 
This may include occasional proclamations on social media of one's sexual, secular, or gender identity. Due to the improbability of such events, they may attract significant amounts of domestic and/or international attention, but not enough to warrant political mobilization amongst the aggregate group. This includes the establishment of some advocacy-oriented pages on social media, but most of which will be insufficient at drawing in much attention. These instances are likely rare and isolated due to heavy censorship on the internet and the repressive nature of a government.

Tier 2 activism is primarily done through social media, but these acts garner a sufficient amount of domestic attention and include "hashtag" campaigns whereby activists get a specific message to trend or create advocacy-based social media accounts and websites that center around a message of equality. Tier 2 movements are moderately organized. Some coordination is involved in the execution of these campaigns. It is important to factor in the level of attention that online activism gets for the fact that it will contribute to the said group's level of clout and ultimately help them muster much needed public awareness. Tier 2 movements are able to more freely organize due to either: (a) increased levels of internet freedom, or (b) the ability to bypass governmental restrictions in states with lower levels of internet freedom, as is the case in some MENA states. The LGBTQ movement in Iran is able to thrive because activists are able to circumvent governmental firewalls by using a variety of popular software applications (Lee 2013). 
Table 1.2: Four Tiers of Online Activism in Authoritarian Regimes

\begin{tabular}{|c|c|c|c|}
\hline Tier 1 & Tier 2 & Tier 3 & Tier 4 \\
\hline $\begin{array}{l}\text { Isolated Instances of } \\
\text { Online Civil } \\
\text { Disobedience } \\
\text { Individual } \\
\text { Advocacy-Based } \\
\text { Facebook Pages or } \\
\text { Twitter Accounts }\end{array}$ & $\begin{array}{l}\text { Coordination of } \\
\text { Social Media } \\
\text { Campaigns (e.g. } \\
\text { "Hashtag" } \\
\text { Campaigns) } \\
\text { Emergence of Some } \\
\text { Informal Online } \\
\text { Organizations } \\
\text { Mobilization } \\
\text { Among the } \\
\text { Collective Group } \\
\text { Ability to Garner } \\
\text { Moderate Amounts } \\
\text { of Attention for the } \\
\text { Cause }\end{array}$ & $\begin{array}{l}\text { Many Informal } \\
\text { Organizations } \\
\text { Proliferate } \\
\text { Several Formal } \\
\text { Advocacy or } \\
\text { Outreach-Based } \\
\text { Organizations } \\
\text { Emerge Outside of } \\
\text { the Movement's } \\
\text { Home State } \\
\text { Group May Have Its } \\
\text { Own Magazine } \\
\text { Group Has Gained } \\
\text { Both Domestic and } \\
\text { International Allies } \\
\text { to Speak on Its } \\
\text { Behalf }\end{array}$ & $\begin{array}{c}\text { Tier } 3 \text { Tactics } \\
\text { Remain Constant, } \\
\text { but Group has Now } \\
\text { Attained Political } \\
\text { Power } \\
\text { Group has Co- } \\
\text { Opted Politicians } \\
\text { and/or Political } \\
\text { Parties } \\
\text { Group Now Poses a } \\
\text { Threat to the State's } \\
\text { Legitimacy } \\
\text { Group is Able to } \\
\text { Pressure } \\
\text { Governments to } \\
\text { Grant Some Policy } \\
\text { Concessions }\end{array}$ \\
\hline
\end{tabular}

When a group's movement has become large and successful enough to qualify

into Tier 3, the movement has become more united and has transcended the internet in some ways. At this point the activism has lead to the proliferation of more formal organizations that are headquartered in less repressive countries. Tier 3 movements also witness the creation of multiple informal online organizations and even magazines (that are either available online or distributed furtively). Most importantly, Tier 3 activists have attained support from some prominent domestic and international allies such as 
celebrities or nongovernmental organizations. It is unlikely that a movement can advance to Tier 3 unless a considerable level of internet freedom is granted to citizens.

Once a movement has advanced to Tier 4 not much of the tactics and mobilization methods have changed from tier 3, but the group has, at this point, garnered a sufficient quantity of political power and now has the capacity to influence policy either by themselves or by procuring/co-opting support from powerful political interests such as state oligarchs, politicians, political parties, and/or wealthy corporations. Tier 4 movements have the capacity to challenge their state's legitimacy, so the internet is no longer essential for the movement's existence. As movements progress to higher tiers their win-sets can be expected to decrease, and conversely, the government's win-set is expected to increase for the fact that the said group in question will pose a larger threat to the social status quo at higher tiers. Tier 4 movements are not common in the MENA, as it requires a regime to be fairly liberalized, if not nominally democratic. This framework is designed to encompass online activism in all authoritarian regimes, so it may also be utilized outside of the MENA region and will be particularly applicable to Sub-Saharan Africa. Categorization of these groups into tiers should not detract from the fact that postmaterialist activism in authoritarian regimes must be measured on a spectrum. While Moroccan and Algerian LGBTQ activists, for example, both qualify into Tier 3, Moroccan activists have progressed further towards the fourth tier than Algerian activists 9.

\footnotetext{
${ }^{9}$ See Chapter 3, Table 3.1
} 
Chapter 2

The Social Status of Sexual \& Gender Minorities

Though gay rights movements materialized in Morocco and Algeria, but not in Tunisia until after its regime change, this should not imply there was not a need for LGBTQ activism in Tunisia. In fact, there is a lack of legal and social equality for gay, lesbian, bisexual, and transgender people in every state in the MENA region, thus making political mobilization a necessity. Members of the LGBTQ community in the Middle East and North Africa are quite possibly more vulnerable and susceptible to prejudice than anywhere else in the world. They are subjected to two forms of discrimination: statesponsored legal persecution and societal marginalization. Out of twenty-two MENA states and territories ${ }^{10}$ homosexuality is only legal in five ${ }^{11}$; male homosexuality is legally prohibited in sixteen of them ${ }^{12}$, whereas female homosexuality is illegal in thirteen

\footnotetext{
10 The states and territories examined are Algeria, Bahrain, Cyprus, Egypt, Iran, Iraq, Israel, Jordan, Kuwait, Lebanon, Libya, Mauritania, Morocco, Oman, Palestine, Qatar, Saudi Arabia, Syria, Tunisia, Turkey, U.A.E. and Yemen. Even though this thesis primarily examines gay rights activism in authoritarian regimes, it will be beneficial to include democratic states such as Israel and Turkey for comparative reasons.

${ }^{11}$ Homosexuality is legal in Bahrain, Cyprus, Israel, Jordan, and Turkey (see BBC 2014).

12 Male homosexuality is illegal in Algeria, Egypt, Iran, Kuwait, Lebanon, Mauritania, Morocco, Oman, the Palestinian territories, Qatar, Saudi Arabia, Syria, Tunisia, U.A.E. and Yemen (Itaborahy and Zhu 2014).
} 
Table 2.1: The Legality of Homosexuality in the Middle East and North Africa

$$
\text { Legal }
$$

Bahrain

Cyprus

Israel

Jordan

Turkey
Legal (Women Only)

Egypt
Iraq
Palestine
Tunisia

Egypt

Palestine

Tunisia
Illegal

Algeria

Iran

Kuwait

Lebanon

Libya

Mauritania

Morocco

Oman

Qatar

Saudi Arabia

Syria

United Arab

Emirates

Yemen
Punishable By Death

Iran

Mauritania

Saudi Arabia

Yemen 
With respect to gender identity—although information on legal framework is sparse - only three states in the MENA region currently allow individuals to undergo sex reassignment surgery: Israel, Turkey, and Iran (TGEU 2014a; Oldershausen 2012). Although sex reassignment surgery is prohibited in Cyprus, they have codified antidiscrimination measures for transgender individuals. Besides Israel it is unknown whether any other state in the region offers protection against discrimination based on gender identity (TGEU 2014a). Additionally, it appears as though every state in the region legally excludes non-binary gender identities ${ }^{16}$ including Turkey and Israel (TGEU 2014b). Under Egyptian law it is legal to prosecute individuals with an androgynous gender, an alternative gender, or for having no gender identity (Ibid). The extent to which other states have legally codified prosecutorial discretion based on deviations from the binary gender system is unknown.

Even upon the repeal of statutes that disproportionately disadvantage members of the LGBTQ community, the climate will not necessarily become less toxic. In Iran, Ayatollah Khomeini-a sworn enemy to gay men and women—is a staunch advocate for transgender rights (Tait 2005). Zarindast and Hashemi (2012) reports that the regime legally mandates insurance companies to cover the entire cost of sexual reassignment surgery (SRS), but in spite of this fact transgender individuals still encounter a gratuitous amount of societal discrimination and are frequently perceived to be cross dressing (Dehghan 2012). In the case of Iraq societal discrimination may have actually increased

\footnotetext{
${ }^{16}$ See "Non-Binary Gender Identity" and "Gender Identity" in Glossary for definitions.
} 
upon legalization of homosexuality. Instances of violence against the LGBTQ community in Iraq have surged since it became legalized in 2003 (Alizadeh 2014). This includes violence perpetuated by the Islamic State (also commonly referred to as 'ISIS' or 'ISIL'), a terrorist organization that has reportedly thrown gay men off of buildings in Mosul (Damon and Bilginsoy 2015).

There is a strong social stigma attached to sexual and gender deviation in every state in the region, but some states stand out when it comes to discrimination. Turkey has the eighth highest rate of recorded murders against transgender people in the world with a total of twenty-three instances of homicide occurring between 2008 and 2011 (TGEU 2012). One can also surmise that bias would likely increase due to intersectionality ${ }^{17}$ of identities (i.e. an individual belonging to two or more types of minority groups).

From a sociopolitical perspective, there is a dearth of egalitarianism with respect to the issue of homosexuality in the region overall. In order to evaluate attitudes towards homosexuality, Pew Research Center (2013) conducted a poll with an average sample size of 962 respondents from seven MENA states and territories ${ }^{18}$ and found that, with the exception of Sub-Saharan Africa, the MENA region is the least tolerant of homosexuality ${ }^{19}$. Feelings towards homosexuality are gauged with a 3-point ordinal level variable utilizing the Likert scale. The frequency distribution indicates a strong aversion

\footnotetext{
${ }^{17}$ See "Intersectionality" in Glossary for definition.

${ }^{18}$ States included in the study are Israel, Lebanon, Turkey, the Palestinian territories, Egypt, Jordan, and Tunisia.

${ }^{19}$ It should be noted that this dataset contains other states, but the MENA region is singled out in this discussion in order to determine attitudes towards homosexuality in the region.
} 
towards the notion of homosexuality; $47 \%$ of Israelis, $78 \%$ of Turks, $80 \%$ of Lebanese, 93\% of Palestinians, 94\% of Tunisians, 95\% of Egyptians, and 97\% of Jordanians believe society should not accept homosexuality (Ibid). With a mean of $83 \%$, median of $93 \%$, and approximate standard deviation of 17 (8 when excluding Israel) it is clear that attitudes towards homosexuality are generally negative ${ }^{20}$. When controlling for nominallevel variables such as age there is not much variation. An increase in age typically leads to a decrease in tolerance for homosexuality - this is the case in many regions such as Latin America, North America, and Europe-but Lebanon is the only state in the region where support amongst younger generations is much stronger than older generations ${ }^{21}$ (Pew Research Center 2013).

These results remain consistent with other datasets. The World Values Survey (2010-2014) measured the justifiability of homosexuality with a 10-point interval-level variable with sample sizes ranging from 1,000 to 2,131 respondents (with a mode of $1,200)$ and found that an average of $68.0 \%$ of MENA citizens from thirteen states ${ }^{22}$ believe homosexuality is never justifiable (V203). In this dataset the most conservative responses came from Qatar, Tunisia, Jordan, and Morocco (with 91.7\%, 87.1\%, 85.6\%,

\footnotetext{
${ }^{20}$ Although one could technically make the case that attitudes towards homosexuality in Israel are heterogenous for the fact that a large portion (40\%) believe homosexuality should be accepted, which indicates views on the matter are polarized (see Pew Research Center 2013).

${ }^{21}$ In Lebanon $27 \%$ of $18-29$ year-olds, $17 \%$ of $30-49$ year-olds, and $10 \%$ of individuals 50 years-old and up believe homosexuality should be accepted; a trend common in many other states, but not those in the MENA region (Pew Research Center 2013).

22 The states/territories included in this dataset are Algeria, Bahrain, Cyprus, Palestine, Iraq, Jordan, Lebanon, Libya, Morocco, Qatar, Tunisia, Turkey, and Yemen.
} 
and $83.6 \%$ all respectively stating homosexuality is never justifiable) while the least conservative responses came from Cyprus at 36.5\% and Bahrain at $42.3 \%$ (Ibid).

In a survey conducted by Gallup, McCarthy (2014) found that citizens in most MENA states do not think their area of residence is hospitable to gays and lesbians; $62 \%$ of Tunisians, $68 \%$ of Turks, $80 \%$ of Palestinians, $81 \%$ of Lebanese, and $91 \%$ of Mauritanians ${ }^{23}$ indicated this view. In sum, these surveys typify a regionally consistent aversion to homosexuality seeing that many individuals believe it is morally repugnant. The small percentage of individuals that are gay, lesbian, bisexual, or transgender — and the even smaller percentage of individuals who will actually opt to "come out" 24 in this region - face severe discrimination due to a strong cultural aversion to the idea of one deviating away from prominent sexual norms.

\section{The Social Climates in Morocco, Algeria, \& Tunisia}

Tunisia has a long reputation of being both a social and legally egalitarian state. It was the first country in North Africa to offer substantial rights to female citizens. President Habib Bourguiba liberalized the Tunisian Personal Status Code in 1956 and granted extensive rights to women upon his state's independence, which was unprecedented for the region (Lust 2013, 796).

Conversely, progress in Morocco stagnated under King Hassan II (Ibid, 664). Once King Mohammed VI inherited the throne, he reformed Morocco’s moudawana

\footnotetext{
${ }^{23}$ Conversely, $49 \%$ of Israelis and $50 \%$ of Cypriots state that their area of residence is hospitable to gays and lesbians, which is quite impressive from a comparative standpoint (McCarthy 2014).

${ }^{24}$ See "Coming Out" in Glossary.
} 
(family code) in 2003 and granted women an extensive set of rights, thus putting them on par with Tunisia and making the country a bit more progressive from a legal standpoint. Lust argues that laws have become more equitable as a result of King Mohammed VI's ambitions to integrate Morocco into the world economy (665). For this reason the importance of both domestic and international legitimacy is evident to King Mohammad VI, as his willingness to modernize Morocco has been quite comprehensive. However, this does not diminish the fact that Morocco is still conservative from a social and cultural standpoint (664).

Algeria, much like Morocco, has a long history of being relatively conservative from both a societal and legal perspective (see Charrad 2001). In 1984 new blatantly discriminatory family codes were codified under President Chadli Bendjedid, which "proclaim[ed] women as minors under the law, and define[d] them as existing only in so far as they are daughters, mothers, or wives" (Salhi 2010, 27). In 2004 President Abdelaziz Bouteflika signaled that change was "imperative" (Watan 2004) and moved forward with the reformation of their family penal codes in 2005 (Marzouki 2010). Article 31 of the Algerian constitution now grants political autonomy to women (Ibid), although they have yet to reach parity with men in many respects. Recent social reformations will not ameliorate decades of cultural conservatism that was reinforced by discriminatory laws, but understanding family codes in these three states allows one to gauge the overall social climate of each state. 
Seeing as how Tunisians have had over fifty years to acclimate to their state's liberal social status codes, one would be reasonable to deduce that this would consequentially result in more egalitarian views towards gay rights. Tunisians may still not be personally inclined to embrace the prospect of social or legal equality for the gay community (seeing as how Pew Research Center [2013] finds that Tunisians are the most averse to homosexuality in the region), but they could potentially be more apt to tolerate its existence than their neighbors.

Tunisia is comparatively more tolerable of homosexuality at least from a legal standpoint. Female homosexuality is legal; only male homosexuality is prohibited (Itaborahy and Zhu 2014, 48). Both male and female homosexuality is unlawful in Morocco and Algeria (Ibid, 40, 30). Predictably, Tunisia is more [legally] indifferent to homosexuality; but in contrast, Morocco and Algeria are not. It is fairly common for the latter two states to persecute and prosecute individuals that violate anti-homosexuality laws, but irrespectively, LGBTQ activism is able to thrive in both places. Persecution Against the Moroccan LGBTQ Community

The Moroccan monarchy exhibits a morally ambiguous attitude towards the notion of homosexuality, but this fact does not imply anti-homosexuality laws go unenforced or that gay and trans Moroccans are not disproportionately targeted in homophobic acts of violence. Anti-sodomy laws are enforced quite fervently by authorities at the local levels. Legal and social persecution against the Moroccan LGBTQ 
community is not only common, but severe to the extent that it made gay activism inevitable once new political resources came to fruition.

While the King has an incentive to cultivate international legitimacy and remain attentive to the growing international sentiment against homophobia, he has largely turned a blind eye to systemic homophobia perpetrated by lower level government officials. Instead of arresting gay men and women for violating Article 489-the Moroccan penal code that criminalizes homosexuality - authorities help perpetuate the facade that Morocco is "gay-friendly" by charging gay people with unrelated offensives such as prostitution or alcoholism while simultaneously being more lenient towards gay tourists (Hayoun 2014a). This is not always the case seeing that Moroccan officials have sparked international outrage in the past by jailing a gay British man in Marrakech, but such an event is out of the norm (Rawlinson 2014). Not all gay tourism is welcome, however, as a gay cruise was diverted away from a port in Casablanca after authorities prohibited it from docking (Gray 2012), but overall, authorities tolerate acts of homosexuality by foreigners insofar as their lack of action does not spark outrage amongst the conservative constituents of local officials and politicians.

Acts of homosexual intimacy are singled out in comparison to other acts deemed sexually immoral. Local police turn a blind eye to heterosexual brothels and allow premarital sex between opposite-sex partners to go unpunished (Ibid). It is estimated that thousands of gay men have been imprisoned for being gay since Morocco gained independence (Harit 2013). While the aforementioned statistic is unsubstantiated, one 
does not have to look far to witness the prevalence of state-sanctioned homophobia. Numerous examples illustrate homophobic abuse by the state.

According to the Index on Censorship (2005) forty men and women were all simultaneously jailed for two days for suspected homosexuality, and additionally, thirteen filmmakers were sentenced to a cumulative total of thirty years in prison for filming sexually explicit videos involving gay men (Rhanem 2006). These instances are not isolated and occur quite frequently. Two men were jailed after being suspected of homosexuality for just sitting in their car together according to Al Arabiya News (2013). Furthermore, the U.S. Department of State (2013, Section 6) cites another case whereby three gay men were sentenced to three years imprisonment for homosexuality. More recently, six men in Fkih Ben Saleh were convicted of homosexuality (Hayoun 2014a). In 2015 two more men were arrested for homosexuality and convicted less than one month later in al Hoceima, which illustrates the ramifications for homosexuality are swift (S. Roberts 2015). These instances only encapsulate cases in which the LGBTQ individuals were actually prosecuted for violating anti-homosexuality laws. One can speculate that many more cases go unreported seeing as how gay men and women may technically be indicted for homosexual acts, but charged with an irrelevant crime (see Hayoun 2014a).

The most prominent case of homophobia paints a bleak picture for Morocco's LGBTQ community for the fact that it highlights both legal and societal persecution. Pfeiffer and Abdennebi (2008) reports that Moroccan authorities raided the house of several men thought to be guilty of allegedly participating in an illegal Sufi-esque 
wedding between a same-sex couple — one of which was believed to be in drag — after an online video of the event surfaced. The family of one of the men involved maintains that no wedding took place at the residence (Ibid). Still, due to persistent coverage and sensationalization, the media may have implicitly incited violence by "smearing" the names of the men involved with the making of the video (Belonksy 2008). As a result the house where the "ceremony" took place attracted a mob of fundamentalists who rioted and ultimately destroyed the house in its entirety according to Pfeiffer and Abdennebi. Belonksy explains that the alleged same-sex wedding video managed to amass a large following and various Moroccan media outlets capitalized on its popularity. One Moroccan newspaper, Al Massae, was fined $€ 100,000$ for inaccurately reporting that a judge was in attendance of the said wedding (Grew 2008). This event is only one of many publicized stories that accentuates the media's ability to exacerbate already homophobic attitudes by sensationalizing LGBTQ stories and vilifying their community.

The Overseas Security Advisory Council (2014) declared that Moroccan LGBTQ individuals encounter "a great deal of [societal] pressure and/or discrimination" in its 2014 Crime and Safety Report. The aforementioned empirical examples as well as others substantiate this point. Gay men and women have a unique challenge in Morocco. One Moroccan lesbian was physically assaulted multiple times in the same week by a disgruntled ex-boyfriend once he learned she had become involved in a romantic relationship with a woman (Hafften 2012). She was disinclined to file a police report for the fact that she anticipated her ex-boyfriend would likely retaliate by reporting her for 
homosexuality, which in turn would subjugate her to imprisonment instead (Ibid).

Violence against the LGBTQ community likely goes unreported quite often for this very reason, which demonstrates that victims have no legal recourse when it comes to homophobic acts of physical abuse.

Moroccan society is very hostile to the notion of homosexuality. Merely bringing up the matter is grounds for outrage. One member of The Party of Justice and Development alleges that public discourse on homosexuality that is perpetuated by NGOs violates the religious values of Moroccans ${ }^{25}$ (Sidiguitiebe 2014). Isolated events such as seminars pertaining to LGBTQ issues are the subject of public outrage when they occur (Hassan Al-Ashraf 2009). Acceptance of even the smallest semblance of contemplation or discussion of homosexuality may be viewed as a tacit endorsement of it (Ibid). The climate for the Moroccan LGBTQ community is undeniably toxic.

\section{Homophobia in Algeria}

There is evidence to suggest the LGBTQ community in Algeria also encounters an immense degree of legal and societal discrimination, although to a lesser extent than gay Moroccans. It is still endemic nonetheless. While news stories involving arrests of the LGBTQ community occur less frequently in Algeria, this does not imply legal persecution is not prevalent, but instead that stories surrounding LGBTQ issues are less sensationalized in comparison to Morocco. Numerous anecdotal examples illustrate that societal discrimination may be a bit more salient in Algeria than in Morocco.

\footnotetext{
${ }^{25}$ It should be noted that this is a rough paraphrasing of what was said seeing that the article in question was translated from French to English.
} 
A transgender woman alleges she has received multiple death threats from religious conservatives and notes that employment discrimination is a common occurrence for her (Tutton 2010). An Algerian gay rights activist, Yahia Zaidi, explains how many gays are subjected to homophobic physical violence (Schweiger 2011). According to the United Nations High Commissioner for Refugees, the LGBTQ community faces severe familial discrimination. Honor killings against gays is a phenomenon that still takes place in Algeria when individuals feel a gay family member has disgraced the family's name (see "UNHCR" 2007). This is one of many reasons why the LGBTQ community is relegated to a perpetual life of secrecy since Algeria's overtly hostile social climate makes the prospect of coming out infeasible (Slimane 2010).

The Algerian LGBTQ community also encounters state-sponsored persecutionprimarily at the local level—as is the case in Morocco (UNHCR 2007). Police often persecute and intimidate gay men and women. Yahia Zaidi was arrested for violating antihomosexuality laws (333 and 338 of the Algerian penal code) and alleges that local authorities plagiarized his signature on a confession form that he refused to sign which professed that he was culpable for acts of homosexuality (Schweiger 2011). This is not the only case of legal maltreatment. Even an imam was sentenced to two years in jail for committing acts of homosexuality (Boudjadi 2010).

The climate for Algerian gays is virulent, but this is no secret. There is no veil of "gay friendliness" in Algeria, which is arguably contrary to the case of Morocco. Pink News (2007) reports that a high court in London rejected a repatriation request of an 
effeminate Algerian man because the court feared his life would be in jeopardy if he returned home. Violence is regularly incited against the Algerian LGBTQ community, as its first gay magazine, El-Shad, alleges it received multiple death threats for merely existing (Harim 2014). Additionally Mufti Yahia, from the Algerian Ministry of Religious Affairs, implicitly advocated for the death of homosexual individuals by stating that it is what the Qur'an suggests should be done to them (Jean-Jacques 2014). This type of rhetoric is dangerous because it resonates with religious fundamentalists who aim to justify and cloak their acts of violence and even honor killings in a shield of legitimacy. Bigotry Against the LGBTQ Community in Tunisia

While acceptance of gay and trans individuals is not the norm in Tunisia, their standard of living is much higher compared to Morocco and Algeria. This is primarily contingent on the fact that female homosexuality is not prohibited, and to boot, the enforcement of anti-homosexual laws against men is seldom (Lucas 2012). Though many gays, lesbians, bisexuals, and transgender individuals opt to stay in the closet, it is sometimes possible for them to come out to their families without facing outright rejection, and this is especially the case in more liberal households where alcohol is consumed and women go unveiled in public (Blackshaw 2012).

In spite of an increased level of social egalitarianism in Tunisia, the situation for the LGBTQ community was never particularly great for a number of reasons. Male homosexuality is illegal, the the collective gay community lacks legal protection from 
discrimination, and same-sex couples are not granted the same rights as opposite-sex couples. This has not changed since democratization.

Canning (2011) reports that Ennahda, Tunisia's largest political party, initially pledged to support the liberty of LGBTQ citizens and inferred that their platform would include support for decriminalization of male homosexuality. However, according to Littauer (2012), Ennahda's Health Minister, Samir Dilou, spoke out against the gay community by stating democratic principles such as freedom of expression should not account for "perversion" and stated his belief that gays need medical treatment, thus implying homosexuality is a mental disorder. The party has since adopted an anti-gay platform as a scare tactic to dissuade voters from electing parties with more secular platforms, although it is quite possible that several internal gay scandals within the party likely triggered the adoption of such a hardline stance on the matter (Ibid).

Furthermore, religiosity has surged since democratization and a discernible Salafist movement has burgeoned (Blackshaw 2012). Seeing as how subscribers of Salafism often adhere to its homophobic tenants it is logical to speculate that this lead to an upswing in societal homophobia. Perhaps for the first time, a tourist was arrested in Tunisia for committing homosexual acts, which was unanticipated considering it is unconventional for authorities in the region to penalize tourists for homosexuality (Morgan 2015).

LGBTQ communities in Morocco, Algeria, and Tunisia face an inordinate amount of discrimination, hence the need for unity and political coordination among the 
aggregate community. However, to publicly advocate for gay equality in the MENA is to commit social suicide and/or incite violence against oneself. For this reason, political mobilization among LGBTQ communities in all three of these states has been done in a manner that is mostly discrete and inconspicuous. 
Chapter 3

Profiling the Strength of LGBTQ Movements in Morocco, Algeria, \& Tunisia

Lesbian, gay, bisexual, and transgender rights movements in Morocco and Algeria — two socially conservative states — are surprisingly robust. Morocco's gay rights movement is more formally organized and prominent than Algeria's; but nevertheless, both are politically active and decent at providing outreach to members of the LGBTQ community. Prior to the 2011 Tunisian revolution, members of the LGBTQ community in Tunisia have not been politically active at all until 2012, which coincides with the time restrictions on internet freedom were lifted. Given that Tunisia has historically been much more socially liberal than its Moroccan and Algerian neighbors, a Tunisian gay rights movement should have theoretically materialized not only before Morocco and Algeria's, but much sooner than it actually did. Seeing that (a) the level of freedom on the internet as well as overall access to it varies in all three of these states, and (b) that the internet has been integral to their LGBTQ movements, it seems plausible to attribute variation in the strength of these movements to the internet. In order to demonstrate this, it is necessary to first determine that there is, in fact, variation in the strength of gay rights movements in Morocco, Algeria, and Tunisia altogether. 
The Moroccan LGBTQ Movement: A Pioneer in North Africa

LGBTQ activism in Morocco is quite prevalent. There is sufficient evidence to suggest the gay movement in Morocco has gained an ample amount of momentum to not only be categorized into the third tier of online activism, but to also be classified as a fullfledged social movement. They have flourished into a well-organized political faction with both formal and informal organizations, LGBTQ-friendly magazines, and notable gay icons (such as Abdella Taia) to represent them and speak out on behalf of the aggregate community. Moreover, it is not untimely to assert that the Moroccan gay movement is on the cusp of advancing to the fourth tier of activism since they arguably pose a small threat to the regime's legitimacy. Their heightened level of international visibility could induce scrutiny on the regime if they call attention to governmental abuse, which keeps the monarchy in check and prevents it from becoming overtly homophobic (which may explain its gay-friendly facade or, at best, apathy towards homosexuality). The ability of gay activists to obtain straight allies such as domestic pro-civil rights organizations (Hayoun 2014a) and international actors (ranging from American and British celebrities to NGOs) has allowed them to increasingly cultivate more political clout at an expeditious pace.

In 2010 King Mohammed VI did not concede to the demands of anti-gay social conservatives whom petitioned him to disallow the British musician, Elton John, from performing at Morocco’s annual Marwazine music festival (Ghanmi 2010). Officials from Morocco's largest Islamic party, The Party of Justice and Development, along with 
Islamists across the country voiced concerns with his performance and argued that permitting such an event could corrupt Moroccan youth by encouraging sexual promiscuity and alcoholism (Ibid). The King disregarded this rhetoric and allowed the performance to take place likely in an attempt to make Morocco appear more modern (Ibid). It is plausible to assume King Mohammed VI's decision was contingent on the fact that he did not want to draw unwelcome international scrutiny to the regime seeing as how it could be detrimental to his economic aspirations and impede his ability to establish international trade deals (Lust 2013, 665).

The King's indifference to homosexuality has put him in a unique political predicament, nevertheless. In an attempt to appease both religious conservatives and social progressives, he walks a fine line. Regardless of the fact that he has yet to indicate support for, nor has he explicitly endorsed any LGBTQ issues, his apathetic view has perpetuated a plethora of rumors that he himself might be a homosexual. The search query “is king mohammed vi gay?” currently turns up 5,630,000 results on Google in Arabic, 430,000 results in English, and 323,000 results in French ${ }^{26}$. This clearly speaks to the fact that many Moroccans are highly conservative when it comes to homosexuality and that anything other than complete and total condemnation of it will result in criticism. This is problematic for the fact that it incentivizes individuals to become unabashedly homophobic in an attempt to appear less suspicious themselves. Irrespectively, the King has allowed openly gay pop stars to return to the country.

\footnotetext{
${ }^{26}$ These results are based off the translation of the search term from English to Arabic and from English to French.
} 
Four years after Elton John's visit Morocco opened the doors to Ricky Martin, who gave a nod to Morocco's LGBTQ community during his performance by changing all female pronouns in his song lyrics to male pronouns (Wong 2014). This example encapsulates the fact that Moroccan gay activists have managed to gain support from gay rights activists abroad, those of which are willing to make statements on behalf of their community (though such a gesture serves little more than symbolism). It also denotes the level of influence the LGBTQ movement in Morocco has attained. They have conveyed a message to the world stating that their situation is dismal and that change is needed.

Morocco’s first formal gay rights organization, Kif-Kif, has existed since 2005 (Bradley 2010, 250). Kif-Kif is a pro-LGBTQ advocacy organization that is headquartered in Spain with approximately fifty staff members (Ibid). Smith (2010) reports that Kif-Kif has been directly instrumental in the creation of Morocco's first gay magazine, Mithly (meaning "the same as me" in English). Their next goal is to construct a “center to provide psychological support" for members of the LGBTQ community in Morocco, but this goal is not within reach at the moment (Association Alouen 2011). Nonetheless, they have been instrumental at fostering discussion about gay rights and are considered a "leader" in the Maghreb (Ibid).

Kif-Kif has faced harassment amid growing levels of eminence. Their web domain has been hacked multiple times by anti-gay Islamic groups (Bradley, 250); still, Kif-Kif has not disbanded. Moroccan activists have proven to be resilient. Though political demonstrations are prohibited in Morocco, LGBTQ activists often participate in 
pride marches abroad, where they are safe to do so (Hayoun 2014b). LGBTQ activism has steadily burgeoned in Morocco since its inception. Its gay rights movement has acquired a substantial level of influence in comparison to other LGBTQ movements in the region. Their presence has, in effect, prevented the monarchy from becoming more abusive, although they have been unsuccessful at pressuring King Mohammed VI to reign in local authorities.

LGBTQ Activism in Algeria: Late Start, Steady Growth

Seeing as how discrimination permeates through Algerian society, there is undoubtedly a need for political mobilization. That is indeed the case. Besides having an LGBTQ magazine, the gay movement in Algeria has progressed to the point to also be categorized into the third tier of postmaterialist activism; however, it is arguably not on par with Morocco's LGBTQ movement. Nonetheless, the movement—also rooted in online activism—-has progressed quite well since its emergence.

There are two prominent LGBTQ associations; Alouen and Abu Nawas. Alouen is an activist organization that prioritizes social equality and advocates for decriminalization of homosexuality and the repeal of penal codes 333 and 338 (see "Association Alouen" in references). On the other hand, Abu Nawas is more outreach-oriented and provides various resources to members of the gay community such as education on safe-sex practices (see "Abu Nawas"). Both organizations specialize in political mobilization; Alouen coordinates events while Abu Nawas encourages LGBTQ citizens to vote (Ibid). Additionally, there are two prominent online-exclusive LGBTQ magazines: Lexo 
Fanzine, a magazine tailored to lesbian issues such as increasing visibility of the women in the LGBTQ community, and Kelmaghreb, which is the male equivalent (Jean-Jacques 2014). Moreover the Algerian LGBTQ community participates in the International Day Against Homophobia and Transphobia (Ibid). According to Afrol News (2010) the LGBTQ Facebook group, “Union des Gays et Lesbiennes en Algérie,” mobilized members of the community to light thousands of candles in public in order to encourage greater visibility of the LGBTQ community and call for the decriminalization of homosexuality.

Algerian activists have also been successful in founding 'TenTen,' the national day of celebration for LGBTQ individuals. Their biggest success, much like the Moroccan LGBTQ community, has been to gain the support of international allies who have called for a repeal of laws criminalizing homosexuality at a UN Human Rights Council event in Geneva on behalf of gay Algerians (Jean-Jacques 2014). With respect to the strength of movements, Morocco and Algeria are fairly similar, but Morocco's movement is a bit stronger and may advance to the fourth tier of activism relatively soon. This is primarily due to Morocco's LGBTQ movement being more formerly organized and having a greater level of international visibility.

\section{The Tunisian LGBTQ Movement: Nonexistent Until Democratization}

It is easier to be a member of the LGBTQ community in Tunisia than in Morocco or Algeria, but there is still an unmistakable need for political mobilization. Nevertheless, there were virtually no signs of LGBTQ activism under Ben Ali’s repressive authoritarian 
regime. Upon his ousting, the first pro-gay Tunisian Facebook page, "Kelmty Associations Gays et Lesbiennes Tunisiens," 27 appeared in 2012 and managed to finally surpass 1,500 likes by March 2014 and currently has over 2,500 likes. Kelmty has since founded a website to act as a portal to their blog and various social media sites. Kelmty differs from groups like Kif-Kif and Alouen in that it does not coordinate pro-equality events or protests, but instead highlights issues that impact the Tunisian LGBTQ community. Moreover, a Maghreb-based online magazine, "Gayday," which covers North African gay issues has managed to gain popularity amongst Tunisia's gay community; although it was not created by Tunisia's LGBTQ community and is instead a regional magazine that is inclusive of them (Littauer 2012).

The Huffington Post (2015) reports that, in addition to Kelmty, more informal organizations have surfaced as of late including several Facebook pages like "LGBTI'28 Tunisien" and "Decriminalization of Homosexuality in Tunisia." The extent of LGBTQ activism in Tunisia is still limited overall. This is because it is a new phenomenon. Once one of the aforementioned groups emerge as the de facto organization for LGBTQ activism in Tunisia - as was the case with Kif-Kif in Morocco and Alouen in Algeriamore coordinated online campaigns should become commonplace. Kelmty seems poised to assume that role.

\footnotetext{
${ }^{27}$ See "Kelmty - Associations Gays et Lesbiennes Tunisiens" 2015 in references.

28 The "I" in this acronym represents inter-sex individuals who are, for the most part, born with ambiguous genitalia. This is an oversimplification since the "inter-sex" label may be applicable in other situations as well.
} 
Figure 3.1: Strength of LGBTQ Movements in Morocco, Algeria, \& Tunisia

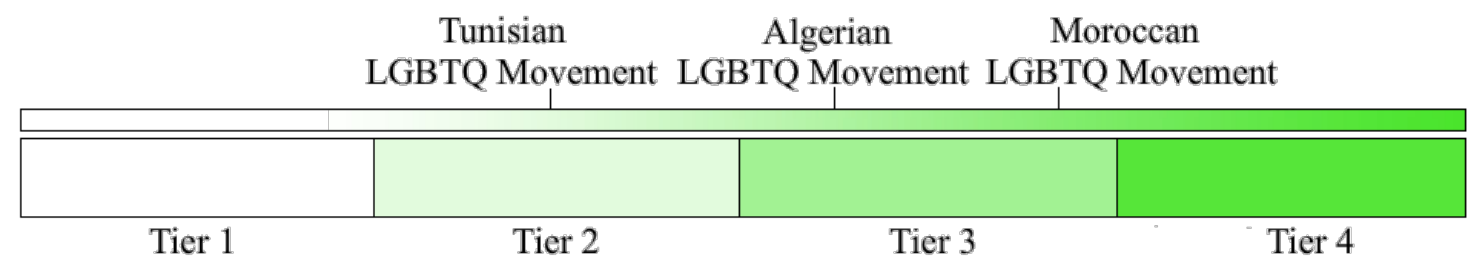

Tunisia's gay rights movement, akin to neighboring Moroccan and Algerian

movements, has progressed steadily since its emergence (see Figure 3.1). Bearing in mind that most of Tunisia's pro-gay organizations are informal and have yet to transcend their online origins, LGBTQ activism in Tunisia can be only categorized into the second tier of online activism. This is mostly due to the fact that its gay rights movement recently developed and activists have yet to coordinate any effective online campaigns. This is quite impressive considering this movement did not meet the criteria for even the first tier just four years ago under Ben Ali. What took so long? Why did LGBTQ activism proliferate in authoritarian Morocco and Algeria, but not in pre-revolutionary Tunisia? What political opportunities would make the development of gay rights movements possible? A literature review of existing theories on what catalyzes social movements will be discussed in the following chapter. 
Chapter 4

Existing Theoretical Explanations

A Tunisian gay rights movement did not exist until after the 2011 revolution, where Tunisia became a democracy. Contrarily, fairly robust LGBTQ movements have existed in Morocco and Algeria since the mid and late 2000s, respectively. This implies the emergence of these movements is attributed to a particular causal factor that was not present in Tunisia until after it democratized. Therefore it will prove fruitful to evaluate theoretical explanations in existing literature to determine which factors are most conducive to the emergence of new social movements and gauge whether they are relevant to the aforesaid cases.

In order to identify casual explanations for the emergence of social movements, it is necessary to first define them. McCarthy and Zald (1977) define social movements as, "a set of opinions and beliefs in a population which represents preferences for changing some elements of the social structure and/or reward distribution of a society" (1217-8). Tilly (2004) cites three components that are fundamental to social movements. First, social movements involve an "organized public effort" (Ibid, 3) that takes shape as a "campaign [which] extends beyond any single event" (4). Second, Tilly argues social 
movements necessitate the building of coalitions, "public meetings, solemn processions, vigils, rallies, demonstrations, petition drives, statements to and in the public media, and pamphleteering" (3). Finally, members of social movements should exert four characteristics that Tilly refers to as "WUNC: worthiness, unity, numbers, and commitment" (4). Melucci (1996) states that individuals within these movements seek to communicate the fact that they have poor standing in society and aim to adjust "cultural codes" to the betterment of their group (9).

\section{Theory of Relative Deprivation and Moral Protests}

There is no paucity of theoretical explanations when it comes to causal factors for political activism, particularly with respect to social movements. However, many theories fail to account for micro acts of social activism or smaller movements and instead focus on more broad macro social movements, namely revolutions wherein dissatisfaction due to governmental or economic factors is widespread. For example, Davies (1962) cites the theory of relative deprivation as an explanation for social movements. He argues that when abrupt stoppages of economic development occurs after elongated periods of economic growth the overall "mood [of society] becomes revolutionary" (5). There is, nevertheless, attention applied to activism surrounding issues of public morality too. Jasper discusses the concept of moral protests; a form of collective action against governmental or societal acts of injustice, ranging from anti-war protests to pro-equality civil rights movements $(1997,3)$. 
Resource Mobilization Theory \& New Social Movement Theory

The emergence of social movements is widely attributed to resource mobilization theory, which is a dominate theory in social movement research (Buechler 1995). Resource mobilization theory posits that activists will mobilize once political resources surface; that is, when new opportunities for collective action manifest (e.g. a larger number of disenchanted individuals feel as though they have something to gain from protesting, organizations develop, new proxies for mobilization emerge, and/or monetary resources become available), this fosters conditions that are conducive to political mobilization seeing that it is now feasible (Reger and Dugan 2001, 337). Conversely, new social movement theory contends that social movements may materialize when dissatisfied actors aim to improve their "quality" of life and coalesce around a group identity in which activism is linked to inextricably (Ibid). Buechler states, "some new social movement theorists emphasize the role of postmaterialist values in much contemporary collective action, as opposed to conflicts over material resources" (1995, 442).

Of these two paradigms, resource mobilization theory is the most suitable in accounting for LGBTQ movements in authoritarian regimes. New social movement theory is cogent, but dissatisfaction alone will not likely suffice as a catalyst for gay rights movements since individuals must be able to engage in activism in the first place. New social movement theory lacks an important ceteris paribus condition: access to a new political resource that makes mobilization possible. The internet is the new political 
resource that makes gay rights activism in authoritarian regimes possible because it diminishes the costs of engaging in political activism. Availability of more discrete and covert options for political protests draws people to the movement since rational actors will be disinclined to engage in activism if it will further jeopardize their standing in society.

There is one reason why social movement theory is probably inapplicable to LGBTQ activism in authoritarian regimes: it cannot explain why gay rights movements do not exist in states where LGBTQ communities share common identities due to governmental and peer marginalization. These conditions should have, according to social movement theory, fostered a common identity strong enough to catalyze gay movements in many states; however, not all states have gay movements despite the existence of shared identities among LGBTQ communities. This indicates a collective identity is not sufficient to catalyze gay movements, which undercuts the utility of social movement theory.

Both paradigms have faults. When it comes to resource mobilization theory, it neglects the role of identity politics in the emergence of social movements, whereas new social movement theory overemphasizes identity politics and omits the importance of new political opportunities. New social movement theory's identity thesis is compelling, but resource mobilization theory's political opportunity thesis is more pertinent given the evidence for what catalyzed LGBTQ movements in North Africa (provided in Chapter 6). Members of the LGBTQ community may want to mobilize due to shared histories, 
identities, and goals, but are unable to do so in hostile autocracies. This implies new social movement theory may be more applicable to LGBTQ movements in democracies. Resource mobilization theory's emphasis on political opportunities is more fitting for LGBTQ movements in authoritarian regimes since it presupposes that individuals with shared identities already want to engage in activism, but will refrain from doing so until they have the ability to, which will be determined by the level of access they have to the internet.

\section{Modernization Theory}

Modernization theory implies the emergence of gay rights movements will be contingent on society's adoption of more modern views, which is dependent on a state's level of economic development. Marks (2009) explains,

as societies develop they become more open, socioeconomic achievements become less tied to social background and other ascribed characteristics, and education becomes more crucial to socioeconomic outcomes. [...] Social background becomes less important and social attainment becomes more universalistic (918).

As education becomes more salient to individuals, their views towards other issues gradually changes and becomes more modern and egalitarian, particularly with respect to issues concerning social equality, ranging from "increasing equality of opportunity in education" to "prohibiting discriminatory practices" (Ibid). As a result of the adoption of these values, movements for these [postmaterialist] causes will begin to materialize, including gay rights movements. The theory itself is highly influential in the field of sociology and political science, but holds only a minimal level of explanatory power 
when it comes to LGBTQ movements in authoritarian regimes seeing that they have already emerged in many regimes that have not yet undergone economic industrialization or diversification.

\section{Additional Hypotheses}

Academic explanations for the development of gay rights movements in developing countries and/or authoritarian regimes are scarce. Nonetheless, there is one by M. Roberts (1995) that is eloquent. He argues that a high prevalence of HIV/AIDS—a crisis which disproportionately impacts gay and bisexual men — could catalyze LGBTQ activism. Gay rights groups in India, Jamaica, and Malaysia organized in an effort to combat the spread of HIV and AIDS within their community by offering treatment and education for safe-sex practices (254). He contends that an Ecuadorian gay rights group formed solely as a response to the HIV/AIDS pandemic (256). In Mexico, the Grupo Orgullo Homosexual de Liberacion, made it one of their foremost concerns in spite of the fact that their formation was not premised on the idea of HIV/AIDS mitigation (Ibid). M. Roberts writes, "the role that gay identification and gay community development plays in reducing risk behavior [...] among gays cannot be underestimated" (260). The application of this hypothesis, however, is limited.

There are three main problems with the aforesaid hypothesis; all of which indicate that it may be inapplicable to LGBTQ activism in the Middle Eastern and North African region. First, the prevalence of HIV/AIDS is not unique to gay communities in many developing countries, especially African states. There is a high prevalence of HIV/AIDS 
among both heterosexuals and homosexuals in Uganda, for example, yet a large gay rights movement still exists (Kuhanen 2008). Many Sub-Saharan African states have high rates of HIV/AIDS among their entire populations, therefore mobilization within gay communities solely to combat the spread of HIV/AIDS seems unnecessary unless there is a significant statistical variation in infection rates between homosexuals and heterosexuals. Second, the prevalence of HIV/AIDS in the MENA region is very low; it is less than $1 \%$ in every state in the region (CIA World Factbook 2014c). Third, this hypothesis applies only to gay and bisexual men and not women. This is problematic because if HIV/AIDS were more prevalent among gay men and could catalyze activism, then one would expect a lack of participation among lesbians and bisexual women, but that is not the case seeing that they actively participate in LGBTQ activism in the MENA. Such a hypothesis is well-reasoned, but likely too outdated to apply to gay rights movements in the MENA.

\section{Explanations of Catalyzing Factors That Are Exclusive to the MENA Region}

Most of the aforementioned theories and arguments demonstrate how and why movements formulate in a more general sense; that is, they apply to many types of movements across a broad range of regime types throughout the world. Competing theoretical perspectives and LGBTQ-specific arguments are valuable, but it is also necessary to explore catalyzing factors for grass roots mobilization that are exclusive to the Middle Eastern and North African region. 
The adoption of free market-oriented neoliberal policies and globalization has contributed to a decline of the middle class in a plethora of states in the Arab world (Bayat 2002, 2). Widespread socioeconomic disenfranchisement in politically restrictive regimes has forced innovation amongst grass roots activists. Bayat argues sociopolitical activism - mostly in Egypt and Iran — manifests in the form of "quiet encroachment," a type of pseudo-movement wherein "direct" action is taken by activists in that they "acquire the basic necessities of their lives (land for shelter, urban collective consumption, informal jobs, business opportunities) in a quiet and unassuming, illegal fashion" (3). For example, citizens will power their shelters by stealing electricity from "municipal power poles" or illegally extend "water pipes to their domiciles" to avoid paying for water (20).

Quiet encroachment may not be politically motivated, but it has inadvertent political consequences. Bayet refers to it as "everyday resistance" since these acts of civil disobedience cost states money (19-20). Socioeconomically disadvantaged individuals in these states are barred from participating in demonstrations, so as a means of procuring basic necessities, they take it upon themselves to obtain them as opposed to pressuring the government to provide it for them. Bayat writes, "informal and often uncharged use of collective services leaves governments little choice but selectively to integrate the informal settlements, hoping to commit the residents to pay for services they have thus far used illegally" (21). 
Alternately, deliberate acts of civil disobedience such as ad hoc outbreaks of riots and mass protests may be triggered by particular events (Bayat 2000). This is demonstrated by the 1980 s riots that transpired throughout the the region (Ibid, 5). In Morocco and Tunisia, reductions in various government subsidies catalyzed mass protests; in Algeria citizens rioted due to a rise in the cost of living (Ibid).

More formally organized political activism in the MENA region often occurs through proxies such as nongovernmental organizations (NGOs) or labor unions (Bayat 2000). Akin to the Western world, labor unions in the MENA - though functionally limited - have been instrumental in organizing strikes and protests due to "distributive issues and unjust labor practices" (7). Similarly, NGOs have been somewhat useful to the extent that their "headquarters also act as a place of sociability, where local poor families can gather outside their homes to associate with other poor" (21). This can be useful for mobilization purposes and also to build solidarity among the socioeconomically disadvantaged, but many NGOs have a more charitable character and mostly use resources to maintain social safety nets for the poor (22). Bayat contends that this is primarily due to a love-hate relationship between NGOs and states. NGOs are unable to bolster grass roots efforts because "surveillance poses a real obstacle to the autonomous and healthy operation" of their facilities (23).

It is also the case that activism begins at mosques. Muslim groups (such as the Muslim Brotherhood) have amassed tremendous amounts of political power. Islamicoriented social movements are able to emerge and thrive due to funding from both 
subscribers of Islam as well as "Muslim businesses," thus allowing them to not only monetarily assist the poor by distributing basic necessities to impoverished Muslim communities, but also to become politically active in order to improve living conditions for other Muslims (16). This can pressure governments to act as they, in effect, are forced to directly compete with these organizations for citizens' allegiance. Bayat explains that the Egyptian government enacted "measures to upgrade slums and squatter areas" in Cairo because Islamic groups had essentially established proxy governments over territories where citizens relied on their goods and services (Ibid).

Though social movement organizations (SMOs) in the Middle East and North Africa often assumes the forms of labor unions, NGOs, and Islamic groups, their existence is not dependent on them altogether. Bayat explains, "urban grassroots groups may find that the community or neighborhood offers a sense of common identity and a ground for collective action" (9). Community activism materializes when a united group coalesces to gain power over issues that impacts them. Bayat explains how citizens have come together to protest the pollution that disproportionately affects their community, or how they have combined resources to lobby politicians (10). Solidarity among communities and the ability of citizens to unite around a common cause is a trend that is typically responsible for catalyzing movements not only in the MENA region, but elsewhere too. Though members of the LGBTQ community have reasons to unite around their common cause, none of these MENA-specific explanations are applicable to the rise of gay activism in the region, as they are in line with the new social movement theory 
school of thought, which is not suitable for the study of LGBTQ movements in authoritarian regimes.

\section{The Cruciality of the Internet to Gay Rights Activism}

Unlike movements motivated by economic factors, members of the lesbian, gay, bisexual, and transgender community face unique obstacles since they are loathed by governments and societies in the MENA. Their ability to forge movements will be entirely contingent upon one fundamental resource for the time being: the internet. This may not be the case for other types of movements, hence the multitude of explanations for their existence, but LGBTQ activism is distinct. Homosexuality and gender deviation are considered social taboo in every state in the region. ${ }^{29}$ Their cause is simply too controversial for public demonstrations to occur.

Muslim-majority countries are highly conservative. The idea of homosexuality is haram; that is, it runs contrary to the teachings of Islam. While not all Muslims will interpret the Qur'an or Hadith to justify homophobia, it is highly unlikely that religious conservatives will be responsive to gay rights messages. LGBTQ communities cannot initiate mass protests, nor can they peacefully demonstrate for three reasons; (i) they comprise very small portions of the populations of each state, and (ii) doing so will result in immediate retaliation, as Arab society is highly conservative and religious, and (iii) public admittance of one's homosexuality or non-cisgender identity equates to a confession of guilt due to the illegality of these identities. For the fact that they lack both

\footnotetext{
${ }^{29}$ Although Iran is an exception with respect to gender identity.
} 
numbers, social acceptance, and legal protection it is infeasible for them to engage in activism unless it is rooted in the online realm.

In the event LGBTQ advocates held a public demonstration, they would likely face severe repercussions; verbal harassment, physical assault, and even could be killed by more fundamentalist individuals. Inevitably, they would also be ostracized by peers, fired from their jobs, and arrested seeing as how they are implicitly admitting to violating legal prohibitions against homosexuality. If the goal is to get their voices heard and pressure their governments to decriminalize homosexuality, it is pivotal that their activism is executed exclusively online, otherwise they will have to travel abroad to participate in other states' gay pride marches. Due to the globalized nature of more visible annual pride parades, they would be competing with many other states' LGBTQ movements for press attention.

There are, of course, exceptions to this unwritten rule. Lebanon is unique in comparison with other states in that its LGBTQ community has participated in actual domestic public protests in front of governmental buildings, many of which have occurred in front of the Ministry of Justice in Beirut (Littaurer 2013; Amand 2012). One notable demonstration occurred due to outrage over six gay and trans individuals being detained for going to a pro-LGBTQ club (Littauer 2013) and another was in response to legislation mandating the use of "anal probe" tests administered exclusively to men in order to "test" them for homosexuality (Amand 2012). Additionally, nearly 200 individuals gathered in Sodeco to advocate equality for the Lebanese LGBTQ community 
(Achi 2009). Had these protests occurred in any other MENA states (excluding Israel, Turkey and Cyprus) swift retaliation from the state would ensue, or rather, a violent counter-protest could erupt.

Since the internet is integral to gay MENA activists, out of all the theories and arguments examined, resource mobilization theory is best able to explain the emergence of LGBTQ movements in MENA authoritarian regimes for two reasons. First, it is premised on the notion that the materialization of social movements is contingent on new political opportunities that make mobilization practicable. Second, the arrival of the internet — the crème de la crème of political opportunities for marginalized groupscoincides with the emergence of LGBTQ movements across the region in terms of timing. The cruciality of the internet to gay activism is illustrated by the fact that the Moroccan, Algerian, and Tunisian gay rights movements all had online geneses. Domestic activism in all three states is extremely rare, and when done, it must occur very quietly unless it is online.

In effect, LGBTQ activists have two options: (a) participate in public activism abroad, or (b) engage in domestic activism almost exclusively online. Tunisian and Algerian activists opt for the latter while Moroccan activists engage in the former. The strength of the Moroccan LGBTQ movement in comparison with its neighbors is much stronger, and to boot, they have existed longer, thus giving them more time to acquire funds and visibility. Public activism is likely more impactful, but due to limited resources, Algerian and Tunisian activists have only been able to mobilize online. 
The internet is essential to gay activism primarily due to its capacity to lower the costs and reduce barriers for actors aiming to engage in it. If the barriers to entry for

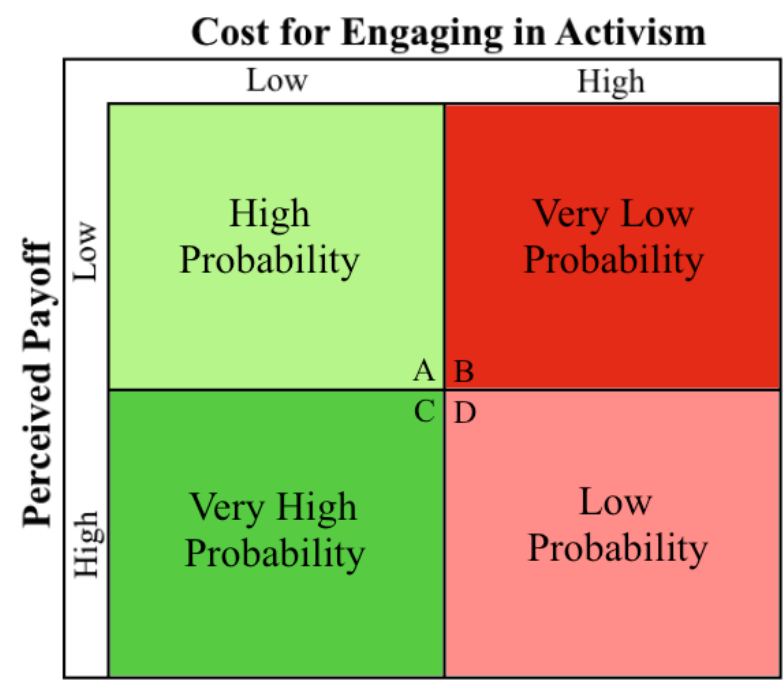

Figure 4.1: Probability for Activism disadvantaged groups are low then one has an incentive to engage in activism to attain a higher social status. This can be explained by contrasting the costs of engaging in activism with the perceived payoff. If a group is not vulnerable and the perceived payoff is low, there will be no incentives to

mobilize. Gay citizens are very vulnerable, and due to high costs, they likely predict a low payoff for engaging in activism without anonymity. The internet virtually eliminates the costs to engaging in activism, thus increasing the probability it will transpire (gay activism can be mapped onto quadrants $\mathrm{A}$ and $\mathrm{C}$ on Figure 4.1 if internet access is adequate). This is why gay rights movements can now emerge in authoritarian regimes.

Other movements also utilize the internet for political mobilization, but worker's rights and environmentalist movements could hypothetically survive without the internet. Few individuals would discriminate against these types of movements because there are collective benefits entailed with protection of worker's rights or the environment. That is not the case when it comes to homosexuality and gender identity. People want to hurt 
them. For this reason, a lack of internet access makes political mobilization of the LGBTQ community virtually impossible due to high costs and a low payoff. 
Chapter 5

Overview of Hypotheses

There are three factors that potentially explain why gay rights movements emerged in Morocco and Algeria, but not in Tunisia until after its democratic transition:

(i) variation in internet access between states, (ii) differences in degrees of governmental, societal, and/or media discrimination, and (iii) increased political liberalization in Morocco and Algeria, but not Tunisia. One of the following three hypotheses may explain variation in the aforementioned three cases, and more broadly, explain the existence of gay rights movements in authoritarian regimes in the MENA altogether:

- $\mathrm{H}_{1}$ : The Internet Mobilization Hypothesis - Once citizens from marginalized groups gain sufficient access to the internet—due increased internet penetration, the expansion of broadband infrastructure, and greater availability of smartphones - and can use it freely, they will utilize it as a tool to politically mobilize and fight back against government and/or societal persecution and repression, thus initiating a new movement. I speculate that this hypothesis will be most apt at explaining why LGBTQ movements exist in authoritarian regimes because resource mobilization theory contends that new political opportunities are required for the materialization of new movements. The 
internet is perhaps the sole medium in which LGBTQ activism is able to exist in the MENA, therefore it can be classified as the political opportunity that makes this type of activism possible.

- H2$_{2}$ : The Social Blowback Hypothesis - When a disadvantaged group encounters a surge of persecution—regardless if the source of bias comes from the government, the media, or other members of society - the aforementioned group will mobilize in order to temporarily push back against this injustice with an episode of activism in response. If episodes of persecution increase in frequency and/or severity, the sporadic episodes of activism could become more persistent and ultimately transform into a sustained movement. This is a wellreasoned hypothesis, however, it seems more fitting for LGBTQ activism in democratic regimes, as it presupposes (a) barriers to the emergence of new social movements are already diminished, and (b) that a sufficient degree of repression is all that is required to catalyze a gay rights movement, but if that were the case nearly every state in the world would have a sizable LGBTQ movement seeing that episodes of persecution against the gay community are very common in most states.

- H3: The Political Liberalization Hypothesis - More robust authoritarian regimes may aim to cultivate both domestic and international legitimacy and extend their longevity by allowing for greater levels of political participation. This may involve loosening prohibitions on public demonstrations and allowing 
opposition parties and other previously repressed political factions to form by holding elections for particular government offices or by facilitating greater inclusion of women and minority groups in legislatures by adopting gender quotas or reserved seats. This will result in the emergence of a plethora of new movements. By doing this the state, in effect, only pays lip service to the idea of pluralism, but it will inevitably catalyze new movements that would not otherwise exist. This hypothesis is likely a practicable explanation for the emergence of many social movements across the MENA region, but not gay rights movements. Political liberalization will be valuable to many groups, but it will not diminish societal homophobia, therefore gay rights movements may still not materialize unless they are able to mobilize in a manner that is discrete and protects their identities.

I expect that the internet mobilization hypothesis will be most able to explain why LGBTQ movements emerge in Middle Eastern and North African authoritarian regimes. The internet mobilization hypothesis can anticipate not only which states these movements will likely take place in, but also the overall strength of these movements. I speculate that one should be able to predict both the existence and size of a state's LGBTQ movement based solely on a comprehensive evaluation of internet penetration rates as well as internet freedom. Nonetheless, the other two aforementioned hypotheses could partially account for the existence of LGBTQ movements as well. Given this 
possibility, I will highlight my reasoning for why all three of these hypotheses could yield at least some explanatory value.

\section{The Internet Mobilization Hypothesis}

The internet allows for political mobilization that is anonymous and inconspicuous. It minimizes the threat of legal or physical retaliation against the group for speaking out. It also lowers both costs and barriers to engaging in activism, and for this reason, it is an invaluable political tool that LGBTQ rights advocates can utilize in order to stake their claim in politics. Internet availability as well as internet freedom has recently become more widely available in the MENA region, therefore it seems logical to attribute the rise of gay rights movements to the internet.

In comparison to the Western world the Middle East and North Africa have lower internet penetration rates, but that is not to say internet use altogether is non-existent. The rate of internet usage ${ }^{30}$ (see Table 5.1) ranges from $1 \%$ in Iraq to $61 \%$ in the United Arab Emirates with a regional average of 26\% (see CIA World Factbook 2014a; 2014b [reference Footnote 30 for methodology]).

In some circumstances governments may undercut the utility of internet access by implementing censorship laws. Amid growing pro-democracy protests in Algeria in 2011, President Abdelaziz Boutifleka’s blocked internet access for many users; numerous citizens reported that their Facebook accounts had been deleted altogether (Ramdani

\footnotetext{
${ }^{30}$ Internet penetration is calculated by converting the ratio of "internet users : total population" into a percentage using internet usage data from CIA World Factbook (2014a) and population size statistics from CIA World Factbook (2014b).
} 
Table 5.1: Internet Penetration in the Middle East and North Africa

\begin{tabular}{|c|c|c|c|c|c|c|}
\hline Algeria & Bahrain & Cyprus & Egypt & Iran & Iraq & Israel \\
\hline $\begin{array}{c}12.1 \% \\
(4,700,000)\end{array}$ & $\begin{array}{c}31.9 \% \\
(419,500)\end{array}$ & $\begin{array}{c}37 \% \\
(433,900)\end{array}$ & $\begin{array}{c}23.2 \% \\
(20,136,000)\end{array}$ & $\begin{array}{c}10.7 \% \\
(8,214,000)\end{array}$ & $\begin{array}{c}1 \% \\
(325,900)\end{array}$ & $\begin{array}{c}57.9 \% \\
(4,525,000)\end{array}$ \\
\hline Jordan & Kuwait & Lebanon & Libya & Morocco & Oman & Palestine \\
\hline $\begin{array}{c}20.7 \% \\
(1,642,000)\end{array}$ & $\begin{array}{c}40.1 \% \\
(1,100,000)\end{array}$ & $\begin{array}{c}17 \% \\
(1,000,000)\end{array}$ & $\begin{array}{c}5.7 \% \\
(353,900)\end{array}$ & $\begin{array}{c}40.1 \% \\
(13,213,000)\end{array}$ & $\begin{array}{c}45.5 \\
(1,465,000)\end{array}$ & $\begin{array}{c}30.3 \% \\
(1,379,000)\end{array}$ \\
\hline Qatar & S. A. & Syria & Tunisia & Turkey & U.A.E. & Yemen \\
\hline $\begin{array}{c}26.6 \% \\
(563,800)\end{array}$ & $\begin{array}{c}35.7 \% \\
(9,774,000)\end{array}$ & $\begin{array}{c}24.9 \% \\
(4,469,000)\end{array}$ & $\begin{array}{c}32 \% \\
(3,500,000)\end{array}$ & $\begin{array}{c}33.4 \% \\
(27,233,000)\end{array}$ & $\begin{array}{c}61.3 \% \\
(3,449,000)\end{array}$ & $\begin{array}{c}9 \% \\
(2,349,000)\end{array}$ \\
\hline
\end{tabular}

Note: Numbers in parentheses are total number of internet users. Mauritania was excluded from the table due to space restraints. Its penetration is $2.1 \%$ (Pop. 3,516,806).

Source: CIA World Factbook 2014a; 2014 b.

2011). The rate of internet usage in Algeria is only $12.1 \%$, and any strangulation of this crucial resource could prove detrimental to a movement. This is not the norm in Algeria. Moroccans and Algerians have enjoyed a substantial degree of freedom on the internet, whereas internet censorship was prevalent for Tunisians under Ben Ali's regime (see Freedom House 2011; Ibid. 2014; OpenNet Initiative 2009a; Ibid. 2009b). Morocco, a state with a sizable gay rights movement with a high level of visibility and influence, has a substantial rate of internet usage at $40.1 \%$ (see Table 5.1) as well a high degree of internet freedom (OpenNet Initiative 2009b). The existence of a large Moroccan LGBTQ movement is consistent with the internet mobilization hypothesis bearing in mind the aforementioned internet statistics. Since LGBTQ movements in all three of these states emerged online — and still occurs online for the most part — the internet mobilization hypothesis is likely capable of explaining the existence of these movements and why they vary in strength. 
The Social Blowback Hypothesis

Blowback is a term that is not necessarily rooted in social activism, nor has it previously had academic underpinnings. It is a term coined by the U.S. Central Intelligence Agency to explain the repercussions of American militarism in the Middle East (Bergen and Reynolds 2005). Blowback is one consequence of U.S. foreign involvement in states such as Afghanistan and Iraq. Airstrikes and the use of drones against terrorist groups such as Al Qaeda and ISIS may result in collateral damage, which could potentially lead to further radicalization of moderate individuals in the region that would not have otherwise joined jihadist movements (Goodman 2013). Blowback is, in essence, a retaliatory response either from individuals that knew someone who became victims of collateral damage or from individuals that feel the U.S. is waging a "war on Islam” (Ibid). An example is the Sunni rebellion that was triggered by the U.S. government's decision to cleanse the Iraqi government of Saddam Hussein's Ba'athist party, which ultimately lead to a civil war between Shias and Sunnis once the new Shia government began to disenfranchise Sunnis.

The blowback theory can be modified to fit sociopolitical settings. Reengineering it to explain why movements for postmaterialist causes emerge can be done in the following manner: if a government subjects a particular group of individuals to an episode of extreme persecution, that group might push back with a retaliatory response (i.e. protesting) against these acts of repression, thus spawning a brief period of activism that could ultimately result in a sustained movement. There are numerous empirical and 
historical examples that are illustrative of "social" blowback. The birth of the American LGBTQ movement surfaced due to the culmination of a months-long episode of legal persecution from the U.S. government (Falk 2014). A police raid on the Stonewall Inn gay bar in 1969 lead to social blowback in the form of riots. Once these dissipated the movement for gay equality remained. Falk writes, "the demonstrations in the days after, became a rallying cry to fight back against the force used against the patrons of the bar that night." If blowback against governmental marginalization catalyzed the American gay rights movement, it should, in theory, be applicable elsewhere.

David Bahati, a member of the Ugandan parliament who introduced the infamous anti-gay bill which sought to make homosexuality punishable by death in Uganda, may be responsible for spawning a wave of gay activism seeing as how LGBTQ Ugandans were compelled to mobilize politically in order to prevent the bill from being codified, but President Musevini ultimately signed a less harsh, albeit still draconian bill into law that made homosexuality punishable by life in prison (Karimi and Thompson 2014). Since this episode gay rights activism in Uganda has become more prevalent. The Ugandan $\mathrm{Kuchu}^{31}$ community created and published their own magazine (Merrill 2015), they have held small pride marches (Muhumuza 2014), and the movement has given given birth to prominent Kuchu activists like David Kato, who managed to garner a substantial amount of international fame for his LGBTQ activism prior to his death

\footnotetext{
${ }^{31} \mathrm{Kuchu}$ is a label gay Ugandans attribute to themselves.
} 
(Gettleman 2011). Is this episode of governmental persecution the cause of the materialization of Uganda's pro-kuchu movement? This seems questionable.

Episodes of persecution from the media or social discrimination may also warrant brief periods of retaliatory activism. This is because the media are a powerful institution. They are both socially and psychologically influential on multiple levels. Media has the capacity to prime individuals and influence their standards of judgment by using a variety of manipulative strategies (see Iyengar, Peters, and Kinder 1993; McCombs 2004; Palau and Davesa 2013; Miles 2013). Moreover, media institutions in the MENA are often complicit with governmental persecution of marginalized groups. The media may cause social blowback by vilifying disadvantaged groups and further contributing to their persecution by encouraging societal homophobia. "EXPOSED!" was the headline of Ugandan's tabloid newspaper, Red Pepper, a media organization that published lists containing names and photographs of individuals that were either gay, lesbian, or suspected of being gay (Abedine and Landau 2014). This publication reinforced the need for political mobilization of Uganda's gay community, but once again, it is questionable whether a direct line can be drawn from these episodes of persecution to the emergence of gay rights movements.

\section{The Political Liberalization Hypothesis}

Extraordinarily repressive regimes will not likely be conducive to environments that allow for the augmentation of many types of movements. As a result, semidemocratic, illiberal, and to a lesser extent, anocratic regimes will be more inclined to 
allow activists to protest as a means of cultivating both domestic and international legitimacy even if a government is not sympathetic to a group's predicament. Allowing individuals to partake in protests will signal to citizens and external observers that they embrace pluralism. Seeing as how the barriers to entry for activists will be lower in these regimes, movements may materialize because, as rational actors, members of disadvantaged groups will have nothing to lose if they are already persecuted and project that a minimal payoff by engaging in political activism.

Though the expansion of political participation will not allow new political parties and social movements to obtain much political power, they do still arise nonetheless. With respect to the three main cases in this thesis, Tunisia has not undergone political liberalization under Ben Ali, whereas both Morocco and Algeria have, albeit incrementally. Therefore it must be determined whether LGBTQ movements emerged in Morocco and Algeria as a direct result of these changes, because admittedly, an underlying level of freedom is required in order for LGBTQ movements to exist in these countries, but whether gradual political liberalization over decades can catalyze gay rights movements — which have augmented since their inception — seems questionable. These questions will be addressed in the following chapter. 
Chapter 6

Explaining Variation in the Strength of Movements

I use a most similar systems research design (MSSD) to assess variation in the strength of movements between Morocco, Algeria, and Tunisia. A most similar systems design (see Charrad's 2001) is a qualitative research methodology that controls for independent variables that may explain variation in the dependent variable through case selection. Given that all three of the selected cases share cultural, religious, ethnic, racial, and linguistic similarities, variation in the dependent variable cannot be attributed to these factors. Charrad utilizes the MSSD research design to explain why family codes are more conservative in Morocco and Algeria than in Tunisia. She finds that the level of solidarity among tribal groupings and state strength will be the main determinants (Ibid, $401)^{32}$. Weaker states with stronger tribes will have more conservative family codes, while stronger states with weaker tribes will have more liberal family codes (Ibid).

My case selection, much akin to Charrad's, is also contingent on variation between three similar states. Both Algeria and Morocco have fairly large LGBTQ rights movements (though the latter is larger), whereas a gay rights movement did not emerge in

\footnotetext{
32 The digital [Kindle] version is referenced. Page numbers will vary from the printed editions.
} 
Tunisia until after it underwent democratization. The fact that these movements emerged in the more culturally conservative states (Morocco and Algeria), but not in Tunisia, one of the most socially liberal states in the region, is perplexing. These dissimilarities (in otherwise comparable states) make it evident that the MSSD methodology is the most pragmatic research design considering the nature of these three cases.

The Tunisian LGBTQ community is comparatively less repressed than most other states in the region, hence it is logical to expect a more sizable community of gay rights activists in Tunisia rather than Morocco or Algeria, but that is not the case. Did the regime change facilitate the emergence of the movement? If this is the case LGBTQ activism should not have emerged in Morocco or Algeria. Therefore, one of two remaining factors must explain this variation: (i) gradual political liberalization in Morocco and Algeria, but not in Tunisia, and (ii) varying degrees of internet access and internet freedom between all three states. What must be understood is (a) why LGBTQ movements did not emerge in Tunisia until after it democratized, and (b) why the strength of Morocco's LGBTQ movement is stronger than Algeria's. An explanation for these differences will yield an answer to my primary research question: what is the catalyst for LGBTQ equality movements in culturally conservative and politically repressive authoritarian regimes?

\section{Variation in Movement Strength is Not Due to Political Liberalization}

The dependent variable — existence/strength of LGBTQ movements—is conspicuous in that it varies across these three cases. One may initially posit that 
democratization alone may sufficiently catalyze a movement, but if democratization is a factor, this does not explain why Morocco and Algeria have such sizable LGBTQ movements even though their regimes have not changed (see Figures 6.1, 6.2). One variable in particular stands out and likely accounts for a significant proportion of variation in the dependent variable: level of access to the internet. Still, an underlying level of political freedom is required for any activism to exist at all. Therefore it will be beneficial to disentangle political liberalization from internet access to see which was more important to the emergence of the Moroccan and Algerian LGBTQ movements.

Political liberalization is the expansion of political participation. This entails loosening of prohibitions that bar particular types of political parties from running for office, allowing public protests, and more inclusionary policies with respect to political participation. When it comes to political liberalization states may only be inclined to expand political participation minimally, but democratization involves a total transfer of centralized power from a dictator, military, or political party to the populace (see Schumpeter 1950). The expansion of political participation is extended to everyone in democracies along with protections on civil rights and civil liberties (see Dahl 1971; Ibid, 1989; Schedler 2002).

\section{Political Liberalization in Morocco}

States have an incentive to liberalize in order to cultivate domestic (as well as international) legitimacy and to extend regime longevity. Joffé (2014) explains that political liberalization has been a gradual process in Morocco that has occurred since the 
Figure 6.1: Polity IV Regime Trends

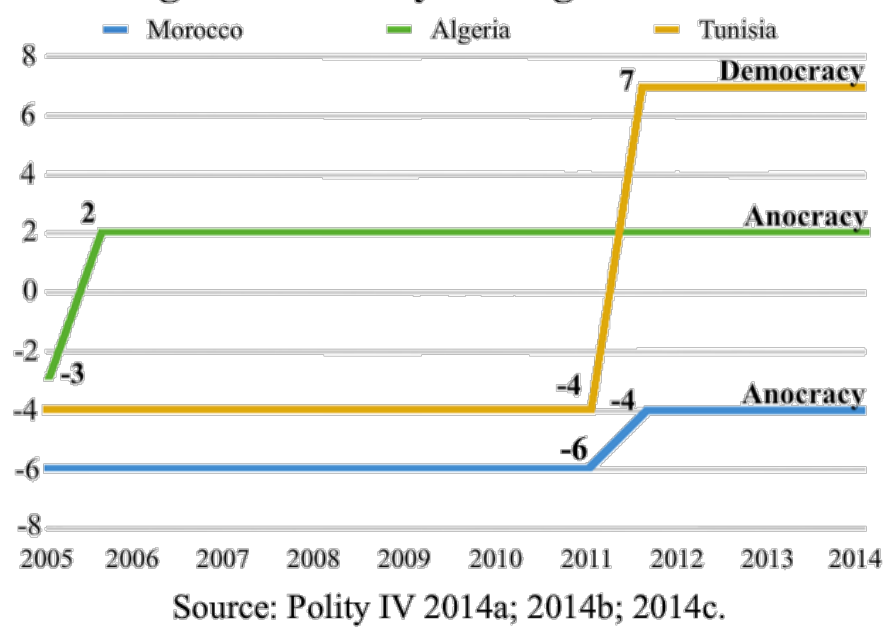

' 80 s. In the early 2000 s

substantial social progress was

made. Laws surrounding women's rights became more equitable due to updates to the Moroccan family code, and the King also championed policies to ameliorate

poverty (Ibid). Political participation has also expanded. Legislative elections occur in Morocco, but the executive branch is held by the King and remains uncontested. The Party of Justice and Development, which is a moderate Islamic opposition party, maintains control over Morocco's bicameral legislature, but many contend they are only a pseudo-opposition party and pose no real threat to the King's monopoly on power (Mekhennet and Baume 2011). A diverse array of political parties are allowed to run, though the monarchy has been successful at co-opting most political opponents (Joffé 2014), so the prospect of substantive political reform or a change in the power structure is unlikely.

When it comes to the materialization of gay rights movements, is it possible that their existence can be attributed to gradual political liberalization? The year when gay rights activism became prominent in Morocco was approximately $2005^{33}$, but according to Polity IV (2014b, Figure 6.1) the Moroccan regime was consistently autocratic with a

\footnotetext{
33 This is the year in which Morocco's first gay rights organization was founded.
} 
score of -6 until 2011, when Polity IV upgraded them to -4 . Prior to this change in ranking, Polity IV gave them a 1-point increase in 1999 from -7 to -6 (Ibid). Between 2004 and 2005 Freedom House (2014) upgraded Morocco's freedom score from 5 to 4.5. However, this slight increase in freedom did not open a window for LGBTQ activism to

Figure 6.2: Freedom House Trends

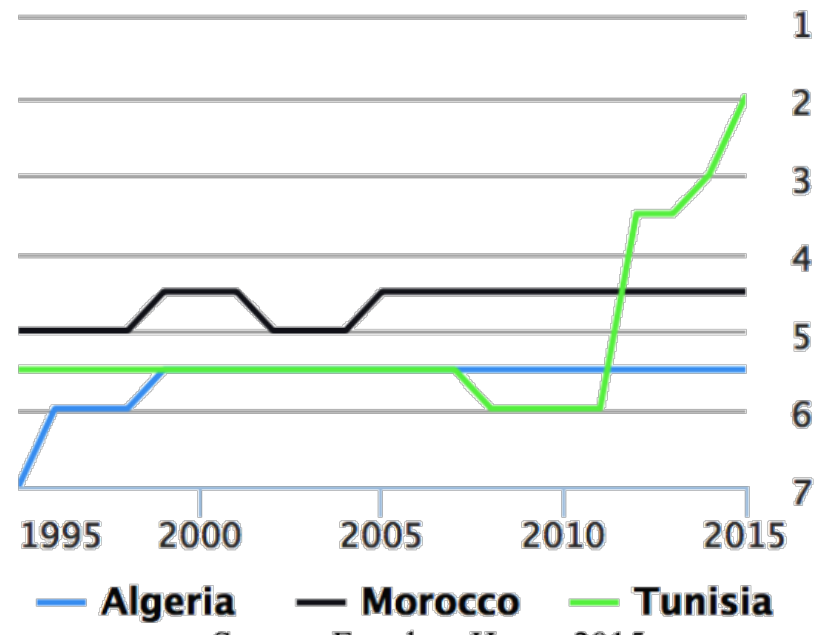

Source: Freedom House 2015. emerge, as Freedom House (2005)

attributes this increase to the

reformation of Morocco's family

codes in 2004, which granted women

extensive rights. The reformation of

Moroccan family law did not benefit

members of the LGBTQ community 34

or increase their net level of freedom.

Morocco has not received a higher score from Freedom House since 2005, and Polity

IV's 2011 regime upgrade occurred after its LGBTQ movement was well underway.

Therefore it can be concluded that political liberalization was not a factor that catalyzed

its LGBTQ movement since any significant political changes that took place did not open the doors for LGBTQ activism. Furthermore, the time periods wherein significant political changes occurred were far removed from the time in which LGBTQ activism emerged.

\footnotetext{
${ }^{34}$ Of course, lesbian and bisexual cis-women benefited due to increased levels of gender equality, but it did not further their ability to practice homosexuality, nor did it help the LGBTQ cause in any way.
} 
Political Liberalization in Algeria

Much like Morocco, Algeria has also liberalized gradually. Though multi-party elections now occur, Algeria is largely a single-party dominant regime. The National Liberation Front (FLN) has a long held monopoly on political power that it has yet to relinquish. Unlike Morocco's executive branch, Algerian presidents must compete in presidential elections, but Freedom House (2013) indicates that these contests are fraudulent and that opposing candidates frequently withdraw from races in protest due to corrupt results.

In spite of increased liberalization, primarily in the form of allowing opposition candidates to run for president, Algeria's Freedom House ranking has consistently remained at 5.5 since 1999 (see Figure 6.2). Between 2005 and 2006 Polity IV upgraded Algeria's regime from -3 to 2, which is a 5-point difference (see Figure 6.1). However, this did not open a window for LGBTQ activism to emerge. Polity IV (2010) attributes the upgrade to increased transparency during the 2004 presidential election. Moreover, LGBTQ activism did not become prevalent until approximately 2009, which is after internet penetration finally surpassed 10\% (Internet World Stats 2012b, see Figure 6.4). Therefore it does not appear as though liberalization has caused an Algerian gay rights movement to emerge, nor has it ameliorated social biases against the LGBTQ community. The years in which Polity IV and Freedom House upgraded Algeria's regime/ freedom scores are distant from the emergence of its LGBTQ movement. ${ }^{35}$ The most

\footnotetext{
${ }^{35}$ Which is in approximately the late ' $00 \mathrm{~s}$, when its first gay rights organization emerged.
} 
recent scoring change by Polity IV (in 2006, see Figure 6.1) was due to greater election transparency, so there is no reason to believe this would directly impact the emergence of a gay rights movement.

Democratization in Tunisia

Tunisia was consistently authoritarian by both Polity IV and Freedom House standards until the revolution (see Figures 6.1 and 6.2 for reference). They did not receive their first score upgrade until 2011; from 6 to 3.5 by Freedom House (2015) and from -4 to 7 by Polity IV (2014a). Prior to democratization Tunisians were prohibited from engaging in political activism. Lutterback describes Ben Ali’s regime as "a police state par excellence," which made it difficult for movements of all types to become politically active $(2013,1)$. Significant political liberalization was the result of democratization in Tunisia. Once Tunisia democratized (and subsequently liberalized politically) a variety of movements came about including a Salafist movement, which was legally barred from existing under the previous regime (Blackshaw 2012). Seeing that the timing of the Tunisian LGBTQ movement's emergence coincided with democratization, it would be easy to attribute the emergence of LGBTQ activism to the regime change. This assertion is incorrect, however, as it omits nuanced details.

The democratization argument, though logical, has two main problems. First, the social climate for gays and transgender individuals did not change upon democratization. While political activists of all stripes — from communists to Salafists — made their political agendas public due to a society-wide inclination to embrace pluralism (seeing as 
how social solidarity made the revolution possible in the first place), the LGBTQ community was perhaps the single group whose views remained marginalized after the revolution (Ibid).

Second, while other new movements such as the Salafist Ansar al-Sharia group, for example, also emerged at approximately the same time as the Tunisian LGBTQ movement, Ansar al-Sharia has participated in multiple public demonstrations with upwards of 100 people (see Al Jazeera 2013; Al Arabiya News 2014), whereas gay rights groups in Tunisia such as LGBTI Tunisien or Kelmty have only been able to participate in online forms of activism. Even though Tunisia has liberalized quite considerably, Tunisian gay rights activists such as Ben Issa and Khaled Azouzi have argued that the social climate is still too hostile for gays to be public about their political agenda (Blackshaw 2012), hence the need for the internet. Without it the LGBTQ movement would not exist in Tunisia. Furthermore, if political liberalization is not what catalyzed gay rights movements in Morocco and Algeria there is no reason to believe it could do so in Tunisia.

Political liberalization and democratization are useful for the materialization of social movements only insofar as there is at least a minimal level of social acceptability for the cause. This is not the case for homosexuality, which is why the internet-as opposed to an abolishment of institutional restrictions on activism via liberalization or democratization - explains the existence of LGBTQ activism in Tunisia. If one could attribute the emergence of Tunisia's gay rights movement to liberalization and 
democratization, one would expect them to be on par with other new movements in terms of strength, but that is not the case. The expansion of political participation in Tunisia was conducive to the emergence of religious, secular, and other ideologically divisive groups (such as communists), but not gay rights groups. Though a gay rights movement exists now, Tunisian activists have not coordinated public demonstrations. Any and all gay rights activism is still forced to remain online due to the unwelcoming nature of Tunisia's social climate; ergo, democratization and political liberalization does not appear to be beneficial to LGBTQ activists. What does facilitate the emergence of gay rights movements is the internet and citizens' ability to use it for political purposes.

\section{The Internet's Key Role in the Variation of LGBTQ Movement Strength}

\section{Variation I: Why Did Activism Not Exist in Tunisia Until After Democratization?}

Looking solely at internet penetration rates (IPR) in Morocco, Algeria, and Tunisia it is evident all states are relatively comparable at first glance. Data from CIA World Factbook (2014a; 2014b) indicates Morocco has the highest IPR at 40.1\%. Tunisia comes in second with an IPR of 32\%, and Algeria's is a modest 12.1\% (see Table 2.4), Data from Internet World Stats — though a bit older-indicates slightly higher IPRs for each country; 49\% in Morocco (2012a), 17.2\% in Algeria (2012b), and 32\% in Tunisia (2012c) [see Figure 6.3]. Raw percentages are somewhat misleading when it comes to why LGBTQ activism did not emerge in Tunisia. A more substantive examination of the level of freedom citizens have to use the internet is required. 
Figure 6.3: Internet Penetration Rate (IPR) Growth

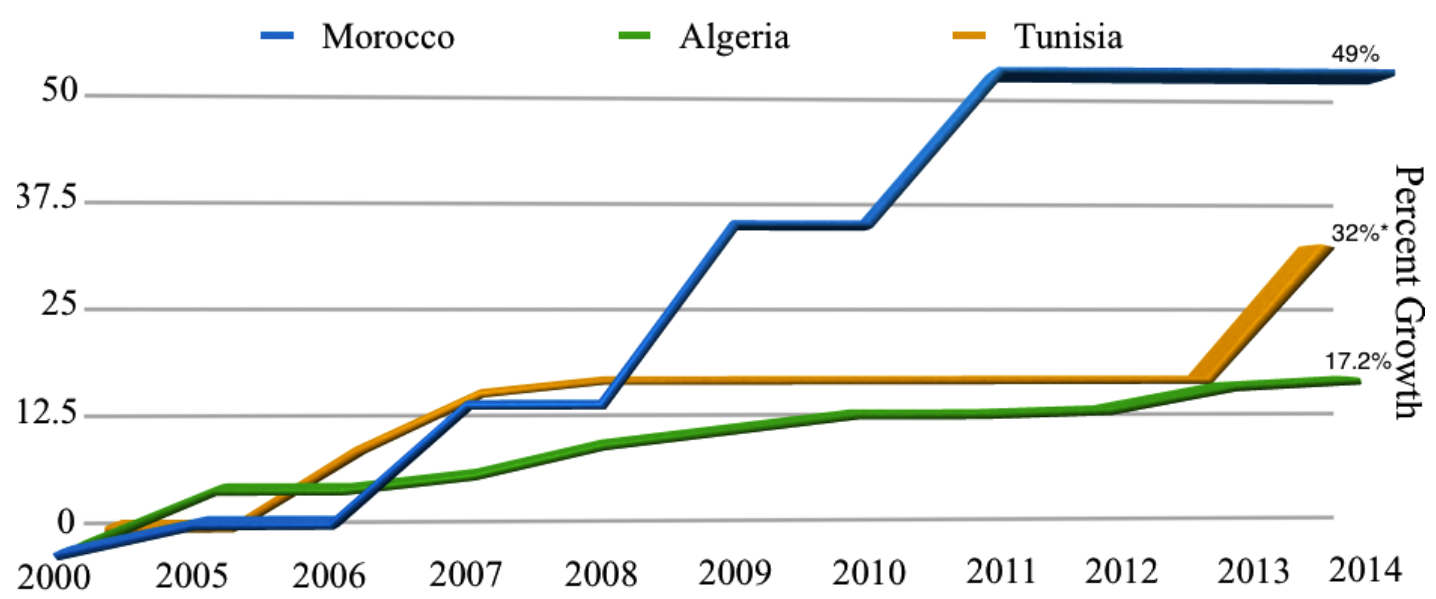

Source: Internet World Stats 2012a; 2012b; 2012c; *CIA World Factbook 2014a; $2014 b$.

In the event $100 \%$ of the population had access to the internet it would not serve as a viable political utility unless citizens were able to use it freely - that is - there is only minimal amounts of governmental interference or restrictions on websites (especially ones used for mobilization purposes such as Facebook, Twitter, and YouTube or their regional equivalents), or citizens have the ability to easily bypass these restrictions. An in-depth examination reveals precisely why a Tunisian LGBTQ movement never took off under Ben Ali; because the Tunisian government was successful at suppressing citizens' freedom on the internet. This has not been the case in Morocco and Algeria.

Freedom House (2014) ranked Tunisia's overall internet freedom as "not free" in 2011 - their last year as an authoritarian regime. Using a 100-point scale, Freedom House scored Tunisia's overall internet freedom 81 out of 100 in 2011 (with 1 denoting total freedom and 100 signaling a complete lack thereof) and explains how there were limitations on content, censorship of political bloggers, and punishment for internet users 
that sought to engage in online political activism (Freedom House 2011). It was not uncommon for the Tunisian government to stringently censor content on the internet and restrict access to websites of the regime's choice.

There was a four-year window when the internet could have been relatively useful as a political tool in Tunisia; particularly between the time infrastructure for broadband was being built ${ }^{36}$ in 2005 up until 2009, which is when the government began to crackdown on the dissemination of user-created content once internet penetration increased (Ibid). Internet access was likely not sufficient to catalyze a gay rights movement by 2005 , and once more citizens finally gained access to the internet their ability to freely use it was restricted. Ben Ali likely saw the internet as a threat to his regime. As internet penetration increased, so too did censorship. Incremental losses in internet freedom was correlated with growth in penetration rates according to Freedom House (2011). There were restrictions to websites that are critical for political mobilization such as YouTube and Facebook. That was not the case with Morocco and Algeria. What has changed since 2011 in Tunisia is its level of internet freedom. As of 2012 Freedom House (2014) upgraded Tunisia’s internet freedom ranking to "partly free" once much of the restrictions were abolished and censorship dissipated after Ben Ali fled the country.

Though Freedom House does not report levels of internet freedom in Algeria (and did not report on internet freedom in Morocco until 2013 [see Freedom House 2014]),

\footnotetext{
${ }^{36}$ Broadband is important namely because faster speeds will allow for uploads/downloads of larger files, such as images and videos, which could prove useful for political purposes in order to document government abuse and share political messages.
} 
there is still evidence to suggest citizens in both states enjoyed a much higher degree of internet freedom. According to OpenNet Initiative (2009a) the Algerian government maintains control over the internet infrastructure, and as a result, it will occasionally utilize it as a security apparatus for surveillance purposes, but the Algerian government does not filter political and/or social content, nor did it do so once internet penetration increased. There are exceptions to this, as the regime attempted to stymie citizens' access to Facebook during the 2011 Arab spring (Ramdani 2011), but this was due to extraordinary circumstances and is not the norm.

There is also no evidence that the Moroccan government heavily censors content on the internet (OpenNet Initiative 2009b). There were particular instances when they selectively filtered some content (such as social media and photo board sites), but this is also rare and typically out of the norm (OpenNet Initiative 2009b). For all intents and purposes, the LGBTQ community in these two states can organize freely online. The consequences of this are evident, as gay Moroccans and Algerians capitalized on internet freedom (as well as increased access to the internet) to initiate their movements.

The idea for Kif-Kif, Morocco’s first formal gay rights organization, manifested on an online forum for LGBTQ people (Association Alouen 2011). As the number of users grew, members sought to become active in politics by formulating an actual organization to represent their interests. Kif-Kif is now considered the leading gay rights association in the Maghreb by its sister movement in Algeria (Ibid). LGBTQ activism is deeply entrenched with the internet. A majority of LGBTQ-tailored resources - ranging 
from magazines to online campaigns - are coordinated and stage exclusively online. The internet is fundamental to LGBTQ activism in authoritarian regimes, and because gay Tunisians were unable to fully take advantage of the access they had to the internet, they were unable to engage in activism or forge a gay rights movement.

Variation II: Why is Morocco's LGBTQ Movement Slightly Larger Than Algeria's in Spite Equivalent Levels of Internet Freedom in Both Countries?

Morocco's LGBTQ movement is slightly more advanced and active than Algeria's, but this can be explained simply by the fact that Morocco has a higher percentage of internet users than Algeria, and additionally, its IPR accelerated more speedily than Algeria's. By the end of 2000 Algeria only had 50,000 internet users whereas Morocco had double that amount irrespective of the fact that Algeria has roughly six million more citizens than Morocco (Internet World Stats 2014). By 2014 Algeria had about 6.7 million internet users, but in contrast, Morocco had four times that amount (Ibid). The rapid expansion of internet access in Morocco in comparison to Algeria makes two things evident: (i) the Algerian LGBTQ movement emerged several years after Morocco's for the fact that Algeria was slower at increasing citizens' access to the internet, and (ii) Morocco's LGBTQ movement is slightly more advanced/active than Algeria's because much more people have access to the internet in Morocco than in Algeria. Furthermore, around the time LGBTQ activism became more prominent in Algeria internet-related factors had recently changed; specifically, internet access became more widely available. 
Belson (2014) demonstrates that Algeria's expansion of broadband infrastructure was substantial in 2013; it increased by $1,000 \%$ (2). This means few LGBTQ activists would no longer be relegated to 56k dial-up and could now navigate more flash-heavy websites, which makes political mobilization less challenging. Web 2.0 sites such as Twitter, Facebook, and YouTube are easily accessible to those with a broadband connection. However, broadband users account for a very small portion of total internet users in the region; approximately $1-3 \%$ in Morocco, 2-4\% in Algeria, and 3-5\% in Tunisia (GSMA 2014, 19). About one in five broadband users in Morocco and Tunisia are smartphone users, whereas just one in twenty Algerians access broadband internet through smartphones (Ibid).

Although IPR statistics are relatively dated, one can expect substantial growth when accounting for the introduction of smartphones to the region. The Middle East and Africa has, since 2011, had the second-largest user base of mobile phone users in the world behind Asia (eMarketer 2013). In 2011 they had 445.6 million users, by 2013 they had reached 525.8 million, and are projected to reach 670 million users by 2017 (Ibid). Mobile phone speeds of $3 \mathrm{G}$ and $4 \mathrm{G}^{37}$ have seen a steady increase of penetration in the region overall, but in comparison with Morocco and Tunisia — whose total 3G/4G smartphone users accounts for approximately $20 \%$ of their total broadband base- - the proportion of Algeria's 3G and 4G mobile phone users makes up less than 5\% out of its entire base of broadband users (GSMA 2014, 19). Much like their internet infrastructure,

\footnotetext{
${ }^{37}$ Speeds above $3 \mathrm{G}$ technically qualifies as broadband while $4 \mathrm{G}$ is a step up from that. Other options, which are particularly slower, are $2 \mathrm{G}$ and lower. The latter speeds are still more common (see GSMA 2014).
} 
Morocco is ahead of Algeria and Tunisia when it comes to $3 \mathrm{G}$ speeds. Morocco rolled out its $3 \mathrm{G}$ network in 2007, which explains why the proportion of fixed to non-fixed broadband users (that is, those with access through a computer versus a mobile device) is higher in Morocco, although Tunisia has been quick to follow due to its small population and geographical size (Ibid, 21). Algeria is also slightly behind Morocco and Tunisia when it comes to cellphone adoption; $16 \%$ of Moroccans and $17 \%$ of Tunisians own cellular telephones in contrast with only $13 \%$ of Algerians (22).

Upon an examination of these statistics it becomes clear that the reason Morocco's LGBTQ movement is slightly stronger than Algeria's is because access to the internet is much higher in Morocco. This is expected when accounting for three factors:

(i) Algeria's population is larger, thus making it difficult to reach more citizens, (ii) geographically, it is larger, which complicates the building of infrastructure, and (iii) its population density is fairly consolidated (with an urbanization rate of over 70\% [CIA World Factbook 2014d]), but there are large pockets of the rural populations dispersed

Figure 6.4: Population Density of North Africa

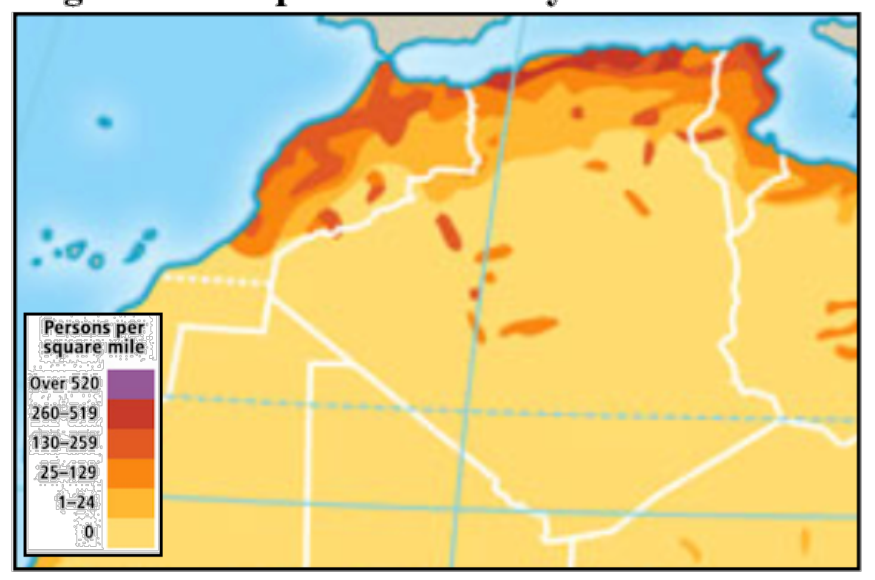

Source: Online Maps 2012. throughout the state (see Figure

6.4). These factors make the implementation of broadband more difficult. Algeria has a lot more ground to cover than its neighbors; specifically, 2,381,741 square kilometers (Ibid). Even when the 
infrastructure is built factors such as reliability, speed consistency, and whether websites and internet hosts have enough bandwidth to handle heavy traffic will impact activists' ability to mobilize. Once internet penetration rates increase, one can expect its LGBTQ movement to become stronger and catch up with Morocco's.

\section{Summary of Primary Findings}

When it comes to the role of the internet, it is very evident that the Tunisian LGBTQ community was unable to emerge for the fact that they lacked adequate freedom to use the internet for political mobilization. Hopkins (2012) explains how Tunisia has long been been known as an "enemy of the internet." Once Tunisia democratized, this trend ceased as of 2012, which is the same year LGBTQ activism began to materialize on Facebook. What is perceptible is the speed in which LGBTQ movements strengthen once they develop. The Algerian LGBTQ movement was insignificant in 2008, but that changed by 2009. Until 2014 the Tunisian LGBTQ movement was virtually non-existent, but now they have become a moderately organized political faction. Tunisia's movement has only advanced to Tier 2 and will likely become a full-fledged Tier 3 movement in a few years time. The strength and growth of these movements will likely continue to accelerate upon greater availability of the internet, granted current levels of freedom on the web remain consistent.

These findings indicate that internet freedom is more important than penetration rates for the existence of LGBTQ movements seeing that even though only a small portion of Algeria's total population has access to the internet, a gay rights movement still 
managed to emerge. However, the overall strength of LGBTQ movements will be determined by growth of internet penetration rates. Internet freedom allows gay rights movements to exist, whereas IPR rates will determine the strength and size of these movements once they materialize.

In terms of internet freedom, all three cases examined in this chapter are now on par. According to Alexa (2015a) websites that are utilized most frequently for purposes of political mobilization (such as social media and video-sharing sites) are incredibly popular. Facebook is the second most popular website in Morocco followed by YouTube, while Twitter is the $21^{\text {st }}$ most popular website. In Algeria and Tunisia, Facebook is the most popular website and YouTube is third most popular (Ibid, 2015b; Similar Web 2014). Even web content that is thought to contribute to social immorality such as pornographic websites are among the most visited sites in these states (Ibid). This indicates that Morocco, Algeria, and Tunisia all allow for an adequate level of internet freedom.

\section{Conclusion}

It is clear that variation in the strength of movements is contingent on differences between levels of freedom on the internet as well as overall access to it. In Morocco and Algeria LGBTQ individuals were able to use the internet freely to mobilize, but in contrast, the Tunisian government heavily blocked content and prohibited websites that could potentially be used for purposes of political mobilization. Once Tunisia democratized and restrictions on internet freedom became more lax, LGBTQ activism 
emerged almost immediately. This is a very important finding that has significant implications on sociological and political science research for social movements.

Additionally, the Moroccan LGBTQ movement is more strong and active than Algeria's, but this is due to greater availability and access to the internet in Morocco. The strength of movements is clearly correlated with the level of access activists have to the internet (see examples in Figure 6.5, modeled after Tammen [2000], 22-23: Figures 1.9 and 1.10). This finding unequivocally validates the internet mobilization hypothesis. The internet was the sole factor that varied across all of these cases, and once internet conditions changed, so too did the dependent variable.

Figure 6.5: Illustration of Movement Strength Crossed by Internet Trends

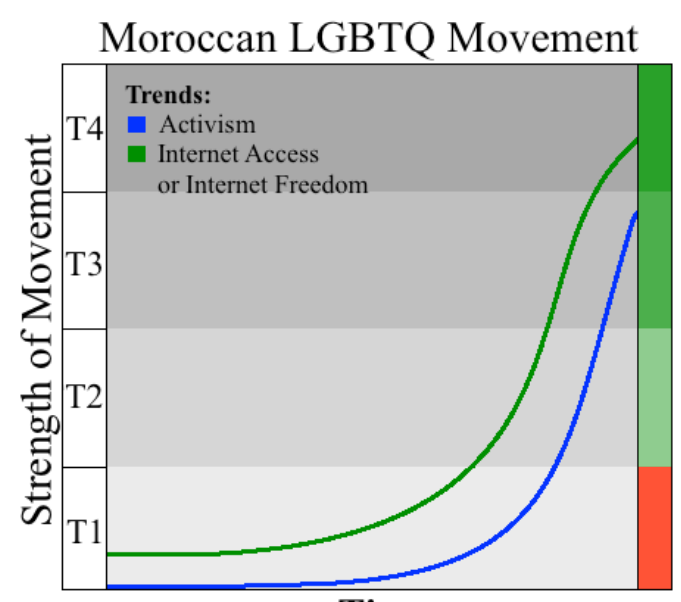

Time

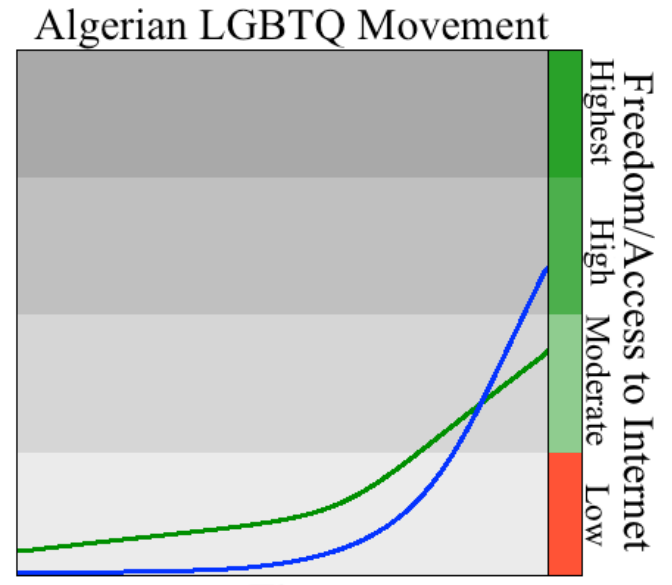

Time

With respect to the social blowback and political liberalization hypotheses, there is a lack of evidence to support both of them. Repression and activism are correlated, but there is no evidence a causal relationship exists. Although there are often intense episodes of persecution waged against LGBTQ communities in these states-especially in Morocco - the overall level of repression against the LGBTQ community has remained 
consistent, so it seems unlikely that episodes of persecution would alone catalyze activism. Episodes of persecution would undoubtedly quantify existing motivations to initiate a gay rights movement, but there is insufficient evidence to suggest it suffices as a catalyst for LGBTQ activism in Morocco, Algeria, or Tunisia.

When it comes to the political liberalization hypothesis, it does not yield much explanatory value in the three aforementioned cases. Political liberalization in Morocco and Algeria did not open new doors for LGBTQ activists, nor did it occur in a time frame that coincides with the emergence of their gay rights movements. Increased liberalization due to democratization in Tunisia also does not explain the emergence of the Tunisian LGBTQ movement. Though it is true that LGBTQ activism emerged after Tunisia democratized and consequentially liberalized, Morocco and Algeria did not democratize and still witnessed the materialization of LGBTQ rights movements. Also, other movements have flourished since democratization in Tunisia and frequently participate in public protests, but LGBTQ activists are still unable to do this for the time being. The liberalization hypothesis may explain why movements for other types of postmaterialist causes exist in authoritarian regimes, but it does not explain the emergence of gay rights movements in this small-N study and will not likely be applicable to LGBTQ movements in other MENA states. Insofar as the three cases in this chapter are concerned, the internet mobilization hypothesis best explains variation in the strength and existence of movements. 
This analysis shows that highly taboo causes such as gay equality movements are able to exist and even thrive in authoritarian regimes in the MENA due to the arrival of new political resources that give them the ability to covertly mobilize online and engage in activism anonymously. Government censorship stymied any and all activism from occurring online in Tunisia, but once citizens were granted the ability to use the internet freely, LGBTQ activists were able to construct advocacy-oriented pages on social media websites and ultimately formed a gay rights movement.

Furthermore, though Morocco and Algeria both have fairly large gay rights movements, Morocco's is slightly larger. Alouen, one of Algeria's leading gay rights groups, refers to the Moroccan gay rights organization Kif-Kif as the leading LGBTQ organization in the Maghreb (Association Alouen 2011), and for good reason. Morocco's collective LGBTQ movement is more sizable and active because the eligibility pool of gay citizens that are able to engage in activism is larger simply due to having more access to the internet. Conversely, many Algerians do not have access to the internet in spite of adequate internet freedom; however, enough citizens have access for a Tier 3 LGBTQ movement to exist. These findings draw us to the following conclusion: internet freedom as well as access to the internet catalyzes LGBTQ movements in authoritarian regimes because gay citizens can avoid social persecution and directly engage in anonymous activism due to their ability to clandestinely organize.

Now that a comprehensive evaluation has been done it is easer to answer the main research question of this thesis; what causes gay rights movements to emerge in 
authoritarian regimes in the MENA? They emerge when new political opportunities materialize - in this case it was the internet. The internet gave LGBTQ activists in Morocco, Algeria, and Tunisia a safe conduit to engage in activism. For this reason, it is now known that LGBTQ movements require the internet and internet freedom to exist in conservative, politically repressive states.

\section{Other Arguments}

There are three other potential arguments that counter the internet mobilization hypothesis. These arguments must be addressed in order to hold that the internet mobilization hypothesis maintains validity. The first posits that the internet is not the de facto method of mobilization for LGBTQ activists in the MENA region since public progay rights demonstrations have taken place in Lebanon; therefore, gay rights activism must not be contingent on the internet. Instead, the internet merely simplifies the process by making mobilization and collective action more streamlined. Second, one cannot identify a 'tipping point' wherein internet access/freedom became prominent enough to allow for the emergence of a gay rights movement. Third, as M. Roberts' (1995) hypothesis predicts, the LGBTQ communities - mostly men - in Morocco and Tunisia are disproportionately impacted by HIV/AIDS in comparison to heterosexuals (Mumtaz et al. 2011), therefore this crisis may have catalyzed a gay rights movement, not the internet.

Argument I: The Role of Internet in Gay Rights Protests 
The first argument contends that the internet is not essential to LGBTQ activism in the MENA region, otherwise public demonstrations by gay rights advocates in Lebanon would not have occurred. Instead, the internet is most commonly used by LGBTQ activists only because it makes political mobilization and coordination easier. The latter component of this counter argument is accurate. The internet has opened the doors for all types of activism. Even existing feminist movements have adopted online campaign strategies to pressure governments. For instance, Saudi feminists now annually initiate calls to defy the female driving ban by devising coordinated hashtag campaigns on Twitter and by uploading videos of themselves driving to YouTube (Naar 2013). There is no reason to doubt the utility of the internet as a tool for activists; however, this counter argument falls apart quickly upon further inspection.

The case of public demonstrations by LGBTQ activists in Lebanon is wholly isolated. Although Moroccan LGBTQ activists, for example, have transcended their online roots, any and all demonstrations or marches occur abroad. Even its chief LGBTQ organization, Kif-Kif, is not headquartered in Morocco, but instead resides in Spain. The Algerian LGBTQ Facebook group, Union des Gays et Lesbiennes en Algérie, was able to successfully mobilize a domestic public protest only to the extent that candles were used as surrogates for the activists themselves (Afrol News 2010). Public demonstrationswhile they are not impossible - are highly unlikely given the social climate in these states. Nevertheless, if one had to select a state whereby the likelihood for a public demonstration is greater, Lebanon would be it. 
Lebanon, much akin to Israel and Turkey, is unique in that homosexuality is comparatively less controversial there. Pew Research Center (2013) indicates that Lebanon is one of the least hostile countries in the region towards the notion of homosexuality; $18 \%$ of respondents believe "society should accept homosexuality." This is in contrast with many other states such as Egypt, Jordan, Tunisia, and the Palestinian Territories where four percent or less believe homosexuality should be accepted (Ibid). This reveals that nearly one in five Lebanese individuals are accepting of the LGBTQ community, thus signaling that public demonstrations - though not the preeminent method - will not be entirely out of the question. Given the large amount of Lebanese citizens that accept homosexuality, this also indicates a substantial proportion of that support comes from heterosexuals, which implies the social climate is more hospitable to gays in Lebanon. Moreover, according to Freedom House (2015) Lebanon is one of few states in the region considered to be "partly free" with an overall score of 4.5. This further illustrates that its political climate is distinct in comparison with its neighbors.

Even if the conditions in Lebanon were less conducive to the possibility of public LGBTQ rights demonstrations occurring, the internet mobilization hypothesis-like all hypotheses - is probabilistic and can account for a small margin of error. However, Lebanese LGBTQ activism would also not exist without the internet since Helem - the region's first formal gay rights organization and coordinator of Lebanese public protest events - exists solely because of it (see Helem 2014). Torbey (2005) writes, “George Azzi, the group's co-ordinator [sic], says the idea first came to life in an internet chat 
room whose members decided to organise an association." This trend is consistent with many other formal gay rights organizations across the region.

The internet is still the main conduit for gays rights activism in Lebanon. Informal online-based organizations like the Lebanese LGBT Media Monitor mobilized effective online campaigns through Twitter such as the \#HammamRaid and \#NoMoreRaids in an effort to raise awareness of instances of legal persecution against individuals in attendance of LGBTQ-friendly clubs (Littauer 2014). Still, the internet mobilization hypothesis does not contend that LGBTQ activism cannot ever transcend its online roots — because that is certainly a possibility — but the initial formulation of gays rights movements in authoritarian regimes is contingent on access to the internet and web freedom. The success of the movement will dictate how long it will be restricted to the online sphere.

\section{Argument II: Lack of Accuracy}

The second argument confronts the fact that it is fairly difficult to pinpoint an exact percentage in which internet penetration becomes sufficient for the emergence of LGBTQ activism. Such an argument is premised on the false assumption that activism will emerge immediately following increased access to the internet. Even in the event it were the case that a tipping point - a percentage in which internet penetration becomes sufficient to catalyze gay rights movements - could be identified, there would be a great deal of planning and coordination on behalf of activists, which would take time, thus implying the emergence would be delayed by a couple of years. However, once internet 
penetration becomes sufficient, by the time a gay rights movement emerges and is visible the IPR would likely change. Another reason it is difficult to identify a precise tipping point is because MENA internet stats are not released annually. For these reasons, pinpointing a precise IPR percentage is onerous.

With the case with Kelmty, an informal gay rights organization in Tunisia, it did not emerge immediately following the revolution. Ben Ali was ousted in early 2011, but the Kelmty Facebook page was not created until 2012. In 2014 it attained 1,500 likes, and by 2015 it finally reached over 2,500 likes and established an official website that directs traffic to its bevy of social media links. It can only recently be classified as an informal organization. This is a seemingly appropriate time frame - two to three years - to discern whether newly created Facebook groups will morph into informal organizations. LGBTQ activism in Algeria had a slow start, but received a boost due to a number of changes in factors related to internet access (increased internet penetration, expansion of broadband, and growth of mobile phone use).

Lastly, specification of an exact percentage of internet access that is required to catalyze LGBTQ movements is unnecessary. Its absence does not detract from the overall validity of the internet mobilization hypothesis. Ascertaining truth about the cause-effect relationship between the internet and LGBTQ activism is what matters most. In the event change in either (a) the existence of gay rights movements, or (b) an increase/decrease in a movement's strength occurs, one can verify that the internet is the cause by observing whether factors such as internet access or internet freedom has also changed. 
Argument III: HIV/AIDS as an Alternate Explanation

Finally, M. Roberts (1995) states that regimes in developing countries fail to target HIV prevention programs towards its LGBTQ communities (248), thus creating an inadvertent gap in knowledge of safe-sex practices within the community. A lack of safesex knowledge almost always overwhelmingly impacts younger demographics. Omission of safe-sex practices in HIV prevention programs for same-sex intercourse is likely dependent on a regime's aversion to or outright denial of the existence of homosexuality. This has been the case in Iran and Russia (see Penketh 2008; Sieczkowski 2014). It may also be because providing such information to gay communities could potentially be seen as a tacit endorsement or legitimization of homosexuality, which may not be culturally permissible. Failure to provide safe-sex education to LGBTQ communities will lead to a greater concentration of those infected within that community (M. Roberts 1995, 248).

This is a reasonable operating hypothesis, however, it is incredibly difficult to control for sexual orientation when attempting to gauge the prevalence of HIV/AIDS in these states. Infection rates among adults between the ages of 15 and 49-years-old are relatively low in Algeria, Morocco, and Tunisia. Approximately only .10\% of citizens in these states are infected (CIA World Factbook 2014c; Sufian 2004). Evidence does suggest that of those few that are infected in the region, gay and bisexual men are impacted disproportionately by HIV/AIDS for the fact that male-to-male sexual contact (MSM) increases one's chances of becoming infected, statistically speaking (Mumtaz et al. 2011). 
A sample size of 1,778 individuals indicates that the rate of infection among gay and/or bisexual males in Tunisia is exceedingly high at $4.6 \%$ - which is nearly one in twenty gay men - although this percentage is lower than the likes of Egypt, Iran, Pakistan, and Sudan (Ibid, 6). A much smaller sample size of 90 gay/bisexual men in Morocco indicates that the rate of infection among them is $4.4 \%$ (Ibid). This is high as well, but the sample size is too small to hold weight. Data on HIV/AIDS prevalence among Algeria's gay community was not collected.

Due to the lack of gay activism under Ben Ali's repressive regime, it seems improbable that a high prevalence of HIV/AIDS among gay and bisexual men would alone catalyze a gay rights movement. If this were the case, assuming the infection rates have remained high among gay and bisexual men, a movement would have likely emerged sooner in order to combat it from spreading further. That is not to say gay/ bisexual men did not desire to combat the spread of HIV/AIDS in their community, but they likely opted not to in order to avoid persecution or being outed. Therefore M. Roberts' hypothesis — if it could be validated — would not necessarily diminish the internet's role in catalyzing gay rights movements no more than the social blowback hypothesis would. Like periods of persecution, HIV/AIDS may enhance existing motivations to engage in activism, but it would not give activists the ability to mobilize.

If it were the case that there was an increased prevalence of HIV/AIDS among gay communities in the MENA, it would be added to a long catalog of reasons why political mobilization of the LGBTQ community is all the more necessary, but the 
opportunity to engage in activism (which is most important) will ultimately be dependent on access to the internet, not AID/AIDS. M Roberts' hypothesis, in part, follows the new social movement line of reasoning, but that theory is more appropriate for explaining why LGBTQ activism emerges in democratic and/or nominally democratic regimes.

Furthermore, M. Roberts' hypothesis is not inclusive of gay and bisexual women, so it cannot explain why they also participate in LGBTQ activism in authoritarian states since he purports that gay men are the only ones impacted by HIV or AIDS. If this were applicable to the MENA, we should expect only gay and bisexual men to fight for gay rights, but that is not the reality. The internet mobilization hypothesis explains why all members of the LGBTQ community engage in activism in authoritarian regimes.

Overall, there is an insufficient amount of evidence to support M. Roberts' HIV/ AIDS hypothesis. That is not to say it is not relevant elsewhere, but it cannot be proven that HIV/AIDS single-handedly catalyzed LGBTQ movements in Tunisia or Morocco. If it could, one would have expected to see the materialization of LGBTQ activism prior to democratization in Tunisia and liberalization in Morocco. This hypothesis is more suited for democracies or nominally democratic regimes seeing that it rests on the assumption that gay rights movements are able to emerge in any social climate, but that is not the case. It is new political opportunities (i.e. the internet) that explains the existence of gay rights movements in authoritarian regimes. 
Chapter 7

Conclusion \& Implications for Social Movement Research

This graduate thesis supports the claim that new political resources affords actors in authoritarian regimes the opportunity to engage in activism. Greater availability and freedom on the internet explains variation in the strength and existence of LGBTQ movements in Morocco, Algeria, and Tunisia. Upon further political liberalization in all three states, gay rights activists were still unable to engage in more orthodox methods of activism (e.g. public demonstrations, lobbying politicians, activism via proxy groups such as human rights organizations, NGOS, unions, or Islamic associations) due to the nature of their causes. The internet was the one conduit with which they were able to convey their message. This finding should change the way sociologists and political scientists think about social movements. The ability of activists to politically mobilize is a key factor when it comes to why movements emerge.

The prospect of equality for sex and gender minorities is too contentious in these states for activists to be open about their political ambitions. They lack political allies to fight on their behalf. Civil rights advocacy groups in the region, by and large, have been unwilling to take up LGBTQ causes. The Egyptian Organization for Human Rights has 
publicly distanced themselves from gay rights activists for "religious and cultural reasons" (Masriya 2014). Such a move may not have been influenced by homophobia, but associating themselves with gays, lesbians, bisexuals, and transgender individuals would most certainly detract from their domestic legitimacy, which could impact their funding and put them in direct opposition with governments, thus threatening their existence. As a result, most domestic groups will avoid adopting gay rights platforms. This leaves members of the LGBTQ community to fend for themselves. The internet has provided them cover in Middle Eastern and North African states. It allows them to stake their claim in politics without the fear of retribution from social conservatives, religious fundamentalists, anti-gay homophobes, or the state. A brief examination of other cases indicates the internet plays a fundamental role in LGBTQ movements not just in Morocco, Algeria, and Tunisia, but throughout the region as well.

\section{A Brief Overview of Other LGBTQ Movements in the MENA}

Lack of an in-depth examination of variables such as regime type, political freedom, internet penetration rates, freedom on the net, and smartphone usage will not produce a nuanced understanding of LGBTQ movements in the region. However, seeing as how it has been established that the internet plays a key role in gay rights activism in the Middle East and North Africa, a brief overview of the methods employed by other LGBTQ activists will still be fruitful in order to demonstrate the overall importance of the internet to their cause. 
Twitter is highly valuable to gay rights activists in the MENA. Hashtag campaigns are a popular tactic primarily because it raises a great deal of both domestic and international attention. Egyptian LGBTQ activists have initiated the “\#SolidaritywithEgyptLGBT" and "\#StopJailingGays” hashtag campaigns (Sheils 2014; Feder 2014). In Lebanon the Lebanese LGBT Media Monitor, an online organization, has been instrumental at coordinating effective hashtag campaigns such as the \#HammamRaid and \#NoMoreRaids in an effort to raise awareness of raids on gayfriendly night clubs (Littauer 2014). These campaigns are mostly initiated by informal organizations that exclusively exist online. These types of advocacy groups have become increasingly common. The aforementioned Lebanese LGBT Media Monitor has attained a significant amount of visibility. Multiple informal online-exclusive organizations have also materialized in Egypt: "Arabs4Tolerance" and "GayEgypt" being two with arguably the most exposure (Masriya 2014).

The LGBTQ movement in Iran, akin to all other movements in the MENA region, was also initiated online (see "Iranian Queer Organization” 2015). Queer Iranians have constructed both formal and informal organizations and have also co-opted domestic and international allies, but activism via social media is the tactic they use most frequently. In 2011 gay and lesbian Iranians uploaded videos of themselves sharing their stories of legal and social persecution (Cohen 2011). Moreover, Tehran's gay community uploaded photographs of themselves with rainbow flags and anti-homophobia signs to an Iranian social networking website (Fisher 2012). Informal organizations that maintain a strong 
presence online have acquired appreciable followings. The Facebook group "Yes People! We Do Exist!" was created in 2012 and has accumulated nearly 6,000 likes (see "Yes People! We Do Exist!" 2015). Iran's LGBTQ movement also relies exclusively on the internet for domestic activism. This is consistent with other LGBTQ groups in the region. Public demonstrations and pride marches are not an option unless they transpire outside of Iranian territory.

Notably, the internet is censored quite heavily in Iran, and as a result, these restrictions may prevent its LGBTQ movement from becoming too powerful (Lee 2013). Irrespectively, a gay rights movement was able to materialize for the fact that many citizens, if not most, are able to circumvent governmental firewalls by using a variety of popular software applications that either mask their IP addresses or generate foreign ones by using VPNs (Ibid). Even though the Iranian government blocks access to popular social networking websites like Facebook (Eremenko 2013), many Iranians are still able to access it according to Lee. For those unable to bypass government censorship, domestic social networking websites such as Joopea are viable alternatives for LGBTQ activists. Gay rights activists in other states with heavy restrictions on internet freedom such as Saudi Arabia (Stern 2014) have not been as successful as Iranians at circumventing governmental restrictions on the internet. The Saudi monarchy has increased internet censorship as of late, and because of this one can speculate that a gay rights movement will not materialize there anytime soon (Ibid). Notwithstanding some 
exceptions, many other MENA states have seen the manifestation of LGBTQ rights movements.

If these movements are becoming more common, why are they ignored by social scientists? Gay rights activism in authoritarian regimes likely does not get attention for three reasons: (i) their movements are comparatively small in contrast with other regional political groups, thereby making them difficult to measure, (ii) information on them is sparse, and (iii) there is a common misconception that either (a) these movements do not exist, or (b) that Western conceptions of homosexuality are foreign to the region.

\section{Why Social Scientists Should Not Forego the Study of Gay Rights in the MENA}

The latter cultural relativist claim is made by Bradley (2010). He critiques "Western-style gays rights activism" in the Middle East and North Africa by stating that it "creates more problems than it solves, if any" (250). This may be true with respect to the social backlash spawned by the emergence of these groups, but Bradley's argument rests on a fundamental misunderstanding of human sexuality. He, in effect, equates male homosexuality to pedophilia, alleging that it is culturally permissible and claims that it "could be fairly described as universal" (242), particularly in Morocco. He says it is common for Moroccan men to engage in sexual acts with prepubescent boys as a means of preserving female purity until marriage (238-9). He holds that this practice, to which he refers to as "pederasty" (referring to sex between a man and a boy), is relatively socially acceptable (238) and contends that the push for gay rights has inadvertently 
jeopardized the social acceptability of pederasty, as it "threaten[s] the peaceful social harmony." (243). He writes,

Pederasty in the Arab world remains as ubiquitous as the call to prayer. So long as the sexual behavior is not spoken of publicly, it does not subvert existing homosocial norms, and it is not therefore perceived as a threat. The trick seems to be to not mention the subject in categorizable terms, not to acknowledge its existence if at all possible, and therefore not to have to deal with its distinct aspect of social reality. (243).

This implies that Bradley advocates for the LGBTQ community to stay in the closet in order to preserve the practice of pederasty. However, pederasty and/or pedophilia is not homosexuality, but instead is a form of child exploitation and abuse. Therefore, Bradley's argument is incorrect because it falsely equates the two.

Also, Bradley's view of homosexuality disregards the existence of lesbianism and bisexuality altogether. Bradley's conception of homosexuality is a gross oversimplification and is blatantly derogatory to members of the LGBTQ community. Homosexuality refers to one's attraction to the same sex and is the persistence of emotional and physical relationships between two consenting adults of the same sex. Studying LGBTQ movements will not "disrupt" the social status quo in the MENA. If anything, shedding more light on them will only bolster their movements. Members of the LGBTQ community face severe discrimination in the MENA, and as a result, it is rational for them to engage in activism granted the opportunity to do so arrises.

Homosexuality transcends culture. It is an innate and naturally occurring biological phenomenon. Although culture is important in that it "provides guidelines or scripts for appropriate sexual responses" (Bancroft 2002, 19), cultural criterions for 
human sexuality does not detract from the plethora of evidence that suggests attraction to the same sex is an irreversible human characteristic and may occur for a number of reasons that are determined by fetal development (Blanchard 2000) or one's genetic predisposition (see Murphy 2005; Gavrilets \& Rice 2009; O’Riordan 2012). Therefore, criticism from cultural relativists is unwarranted for the fact that homosexuality is not a choice and will be just as prevalent in the Middle East and North Africa as it is in Western states regardless of restrictive cultural norms.

Whitaker (2006) states, “Arabs nowadays have just too much contact with the rest of the world to maintain an isolationist 'cultural purity' approach" (224) and adds that “exposure to foreign ideas and influences cannot be prevented" (212), which explains the popularity of the 'LGBTQ' acronym in the region. It is an acronym that maintains synonymity with the global gay community and encapsulates the totality of people participating in the worldwide movement for equality of sex and gender minorities. ${ }^{38}$

Gay rights movements in the global South are equally legitimate to their Western counterparts, therefore social scientists should not be weary of having a "Western bias" when it comes to homosexuality in foreign cultures. Foreign gay rights movements should be included in social movement research. The geneses of these movements is

\footnotetext{
${ }^{38}$ This does not imply that there is a lack of diversity from a linguistic standpoint since each language has its own unique politically correct term(s) to describe gays and lesbians, such as "kuchu" in Uganda, or "mithli" and "mithliyya" for gay men and women in several MENA states (Whitaker 2006, 14), although this does vary. Nonetheless, most gay and trans Arab activists observed throughout the duration of this study self-identify with the 'LGBTQ' moniker, but cultural relativists still deny the universalization of LGBTQ rights.
} 
transpiring at this very moment. Studying them will provide insight into how controversial causes evolve into movements in the era of technology.

\section{Conclusion}

The internet should be scrupulously examined in authoritarian regimes across the globe in order to develop insight into other potential ways activists are utilizing it to pressure governments and push their causes. As access to the internet increases, so too will the size of these movements. Though the scope of this study is limited to three case studies, the applicability of the internet mobilization hypothesis is not restricted to Morocco, Algeria, and Tunisia, nor the aggregate MENA region. Colombant (2010) reports that LGBTQ activists in many Sub-Saharan African countries are also employing online strategies to combat social and legal discrimination. This is evident in Uganda, but is also applicable to the Russian LGBTQ movement as well. For this reason, I believe my methodology will prove useful for assessing what catalyzes these movements and what determines their overall strength in other authoritarian states throughout the world.

The political implications of the internet mobilization hypothesis may even extend beyond LGBTQ movements. It may also prove useful for other types of controversial movements for postmaterialist causes such as atheist, agnostic, areligious, anti-theist, and deist (AAAAD) movements seeing as how they are equally vilified, especially in Muslim-majority MENA states, thus making the internet a necessity for mobilization of their community as well. Social movements that would otherwise not exist could soon be materializing due to the internet. 
All types of activists - both material and postmaterial — have used the internet to facilitate collective action and pressure regimes. Various types of episodic movements around the globe have also been instigated online, including small-scale anti-military protests in Russia to large-scale revolutions which lead to the ousting of dictatorial leaders in the Arab spring (Lonkila 2008; Lynch 2012; Lust 2013). Implications of the internet on culture, religion, and governance can only be speculated, but its impact on social movements is evident.

The aim of this graduate thesis is to ultimately understand why gay rights movements exist in authoritarian regimes in the Middle East and North Africa. Although the MENA is heterogenous, citizens of states in this region are rational actors that are no less likely than anyone else to aspire to attain freedom and equality in society. One's decision to engage in a pursuit to impact public policy will not ensue unless the proper conditions — namely, adequate access to the internet — are sufficient since it is not pragmatic for advocates of controversial causes to engage in activism without anonymity.

The notion of a 'clash of civilizations' is faulty with respect to gay activism and does not hold much weight in an era of globalization and expanded access to new technology. Although there are cultural, religious, and linguistic differences with respect to sexual orientation and gender identity, the inclination of cultural relativists to peg emerging postmaterialist causes as Western phenomena is not grounded in logic, nor is it empirically or factually verifiable. Instead, these movements have been delayed in the MENA not because homosexuality does not exist there, or because they want to emulate 
the West, but because they have not had access to a viable political resource - the internet —until recently. This argument strengthens resource mobilization theory and emphasizes the importance of political opportunities in the emergence of new social movements.

Like-minded individuals are coming together throughout the region to improve their social status and stake their claim in politics. LGBTQ activism in the Middle East and North Africa is not going anywhere, but the question rather is how much momentum these movements will gain in the near future considering how big they have become given the short period of time for which they have existed. Political scientists contend that the Arab uprising, an extraordinary political phenomenon, transpired due to access to new technology (Lust 2013; Lynch 2012; Hussain \& Howard 2013). The internet was cited as a key tool for Arab activists seeing that it was useful for mass political mobilization in 2011 (Lust 2013, 283). This graduate thesis demonstrates that the internet can catalyze other types of activism as well: gay and transgender equality movements. The political landscape in the Middle East and North Africa will likely continue to transform due to the increasing prominence of the internet. 
References

Abedine, Saad and Elizabeth Landau. 2014. "Ugandan Tabloid Prints List of 'Homosexuals'.” CNN. 25 February, 2014. Web. (Accessed: 24 March, 2015). $<$ http://www.cnn.com/2014/02/25/world/africa/uganda-anti-gay-law/>.

Abu Nawas. “About Us! A Rebrique for us Connetr.” Web. (Accessed: 25 March, 2015). $<$ http://abunawas-algerie.e-monsite.com/pages/qui-sommes-nous-une-rebriquepour-nous-connetre.html>.

Achi, George. 2009. "Peaceful Rally in Beirut for Gay Rights.” Monthly Review. 23 February, 2009. Web. (Accessed: 27 March, 2015). $<$ http://mrzine.monthlyreview.org/2009/achi230209.html $>$.

Afrol News. 2010. “Algerian Gays Lit Candles for Recognition.” 13 October, 2010. Web. (Accessed: 25 March, 2015). $<$ http://www.afrol.com/articles/36770>.

Al Arabiya News. 2013. "Lawyer: Two Moroccans Jailed for Homosexuality." 21 May, 2013. Web. (Accessed: 25 March, 2015). $<$ http://english.alarabiya.net/en/News/middle-east/2013/05/21/Lawyer-TwoMoroccans-jailed-for-homosexuality-.html>. . 2014. “Tunisian Police Disperse Islamic Protestors.” 12 April, 2014. Web. (Accessed: 6 May, 2015). $<$ http://english.alarabiya.net/en/News/2014/04/12/Calm-returns-after-TunisianSalafist-protest.html>. 
Alexa. 2015a. “Top Sites in Morocco.” Alexa Internet, Incorporated. Web. (Accessed: 8 May, 2015).

$<$ http://www.alexa.com/topsites/countries/MA $>$.

- 2015b. "Top Sites in Algeria.” Alexa Internet, Incorporated. Web. (Accessed: 8 May, 2015).

$<\mathrm{http}: / /$ www.alexa.com/topsites/countries;0/DZ>.

Alizadeh, Hossein. 2014. "When Coming Out Is a Death Sentence: The Rising Tide of Violence Against LGBT Iraqis.” The Huffington Post. 26 November, 2014. Web. (Accessed: 20 March, 2015).

$<$ http://www.huffingtonpost.com/hossein-alizadeh/when-coming-out-is-adeat_b_6201210.html>.

Al Jazeera. 2013. "Salafist Group Clashes With Police in Tunisia.” 20 May, 2013. Web. (Accessed: 6 May, 2015). $<$ http://www.aljazeera.com/news/africa/2013/05/20135198155650292.html>. Amand, Jason. 2012. “Lebanese LGBT Group Protests Against Gay Anal Testing.” Edge Media Network. 16 August, 2012. Web. (Accessed: 27 March, 2015). $<$ http://www.edgeboston.com/news/international/news/136092/lebanese_lgbt_gro up_protests_against_gay_anal_testing>.

Association Alouen. “Our Mission.” Web. (Accessed: 25 March, 2015). $<$ http://alouen.org/notre-mission/>. 
2011. “Kif-Kif: Une Association Qui a Su Briser les Tabous.” 10 October, 2011.

Web. (Accessed: 7 May, 2015).

$<$ http://alouen.org/kif-kif-une-association-qui-a-su-briser-les-tabous/>.

Bancroft, John. 2002. "Biological Factors in Human Sexuality.” The Journal of Sex

Research 39 (1): 15-21.

Bayat, Asef. 2000. "Social Movements, Activism and Social Development in the Middle East." United Nations. United Nations Research Institute for Social Development, Programme Paper Number 3. Web. (Accessed: 6 May, 2015).

$<$ http://www.unrisd.org/80256b3c005bccf9/(httpauxpages)/9c2befd0ee1c73b380 $256 \mathrm{~b} 5 \mathrm{e} 004 \mathrm{ce} 4 \mathrm{c} 3 /$ file/bayat.pdf $>$.

—. 2002. "Activism and Social Development in the Middle East." International Journal of Middle East Studies 34 (1): 1-28.

_. 2005. "Islamism and Social Movement Theory." Third World Quarterly 26 (6): 891-908.

BBC. 2014. "Where is it illegal to be gay?." BBC News. 10 February, 2014. Web. (Accessed: 20 March, 2015). $<$ http://www.bbc.com/news/world-25927595>.

Belonksy, Andrew. 2008. "Moroccan Paper Fined for 'Sexual Perversion’ Smear.” Queerty. 25 March, 2008. Web. (Accessed: 25 March, 2015). $<\mathrm{http}$ ://www.queerty.com/moroccan-paper-fined-for-sexual-perversionsmear-20080325 > 
Belson, David. 2014. "State of the Internet." Akamai 7(4): 1-62. Web. (Accessed: 7 May, 2015).

$<\mathrm{http}: / /$ www.akamai.com/dl/content/q4-2014-soti-report.pdf $>$.

Bergen, Peter and Alec Reynolds. 2005. “Blowback Revisited: Today’s Insurgents in Iraq Are Tomorrow's Terrorists." Foreign Affairs 84 (6): 2-6.

Blackshaw, Anna. 2012. "After the Arab Spring, the Future is Uncertain for Muslim Gay Youth.” Indy Week. 19 September, 2012. Web. (Accessed: 25 March, 2015). $<$ http://www.indyweek.com/indyweek/after-the-arab-spring-the-future-isuncertain-for-muslim-gay-youth/Content?oid=3152028>.

Blanchard, Ray. 2000. "Fraternal Birth Order, Maternal Immune Reactions, and Homosexuality in Men.” Politics and the Life Sciences 19 (2): 157-159.

Boudjadi, Kamel. 2010. “Gay Imam Gets Two-Year Jail Sentence in Algeria.” San Diego Gay \& Lesbian News. 14 April, 2010. Web. (Accessed: 25 March, 2015). $<$ http://www.sdgln.com/news/2010/04/14/gay-imam-gets-two-year-jail-sentencealgeria\#sthash.n7CKHr9h.dpbs>.

Bradley, John. 2010. Behind the Veil of Vice: The Business and Culture of Sex in the Middle East. New York: Palgrave Macmillan.

Buechler, Steven. 1995. "New Social Movement Theories.” The Sociological Quarterly 36 (3): 441-464.

Canning, Paul. 2011. "Tunisian Islamists Offer Reassurance to Gays, Women, Drinkers." Care2. 25 October, 2011. Web. (Accessed: 24 March 2015). 
$<$ http://www.care2.com/causes/tunisian-islamists-offer-reassurance-to-gayswomen-drinkers.html>.

Charrad, Mounira. 2001. States and Women's Rights: The Making of Postcolonial Tunisia, Algeria, and Morocco. Berkeley: University of California Press.

CIA World Factbook. 2014a. "Country Comparison: Internet Users." United States. Central Intelligence Agency. Web. (Accessed: 24 March, 2015).

$<$ https://www.cia.gov/library/publications/the-world-factbook/rankorder/ 2153rank.html>. . 2014b. "Country Comparison: Population.” United States. Central Intelligence Agency. Web. (Accessed: 24 March, 2015). $<$ https://www.cia.gov/library/publications/the-world-factbook/rankorder/ 2119rank.html>. . 2014c. "Country Comparison: HIV/AIDS - Adult Prevalence Rate.” United States. Central Intelligence Agency. Web. (Accessed: 24 March, 2015). $<$ https://www.cia.gov/library/publications/the-world-factbook/rankorder/ 2155rank.html>. . 2014d. "Africa: Algeria.” United States. Central Intelligence Agency. Web. (Accessed: 7 May, 2015). $<$ https://www.cia.gov/library/publications/the-world-factbook/geos/ag.html>. 
Cohen, Dudi. 2011. "Gay Community in Iran Launches Facebook Campaign Against Regime that Views Their Sexual Identity a Crime Punishable by Death." Y Net News. 12 September, 2011. Web. (Accessed: 28 March, 2015). $<$ http://www.ynetnews.com/articles/0,7340,L-4121043,00.html>.

Colombant, Nico. 2010. “Africa’s Gay Activists Use Internet to Advance Homosexual Rights.” Voice of America. 14 June, 2010. Web. (Accessed: 8 May, 2015). $<$ http://www.voanews.com/content/africas-gay-activists-use-internet-to-advancehomosexual-rights—96381899/154893.html>.

Dahl, Robert. 1971. Polyarchy; Participation and Opposition. New Haven: Yale University Press. 1989. Democracy and Its Critics. New Haven: Yale University Press.

Damon, Arwa and Zeynep Bilginsoy. 2015. “Amid Brazen, Deadly Attacks, Gay Syrians Tell of Fear of ISIS Persecution.” CNN. 6 March, 2015. Web. (Accessed: 20 March, 2015). $<$ http://www.cnn.com/2015/03/05/middleeast/isis-lgbt-persecution/>. Davies, James. 1962. “Toward a Theory of Revolution.” American Sociological Review 27 (1): 5-19.

Dehghan, Saeed. 2012. “Iran's Persecution of Gay Community Revealed.” The Guardian. 17 May, 2012. Web. (Accessed: 28 March, 2015). $<$ http://www.theguardian.com/world/2012/may/17/iran-persecution-gay-commun ity-revealed $>$. 
Encyclopedia Britannica, Inc.. 2008. "Postmaterialism.” Dictionary.com. Web.

(Accessed: 16 March, 2015).

$<$ http://dictionary.reference.com/browse/postmaterialism $>$.

eMarketer. 2013. "Smartphone Usage to Nearly Double in the Middle East and Africa." 1

October, 2013. Web. (Accessed: 7 May, 2015).

$<$ http://www.emarketer.com/Article/Smartphone-Usage-Nearly-Double-MiddleEast-Africa/1010249>.

Eremenko, Alexey. 2013. "Iranian Atheists: Waiting to Come Out.” Sputnik. 19 March, 2013. Web. (Accessed: 28 March, 2015).

$<$ http://sputniknews.com/analysis/20130319/180108603.html>.

Falk, Pamela. 2014. "LGBT rights 45 years after the Stonewall riots.” CBS News. 27

June, 2014. Web. (Accessed: 23 March, 2015).

$<$ http://www.cbsnews.com/news/lgbt-rights-45-years-after-the-stonewall-riots/>.

Feder, J. Lester. 2014. “LGBT Egyptians Go Into Hiding As Regime Cracks Down.”

Buzzfeed. 23 September, 2014. Web. (Accessed: 29 March, 2015).

$<$ http://www.buzzfeed.com/lesterfeder/why-egypts-regime-has-launched-a-masscrackdown-on-lgbt-righ\#.rpvnJ1bkb>.

Fisher, Max. 2012. "Photos of Clandestine Gay Rights Rally in Tehran." The Atlantic. 22

May, 2012. Web. (Accessed: 28 March, 2015).

$<$ http://www.theatlantic.com/international/archive/2012/05/photos-of-a-clandestin e-gay-rights-rally-in-tehran/257500/\#slide9>. 
Freedom House. 2005. "Freedom in the World: Morocco.” Web. (Accessed: 8 May, 2015).

$<$ https://freedomhouse.org/report/freedom-world/2005/morocco\#.VUwz0b64ldg>.

—. 2011. "Freedom on the Net: Tunisia." Web. (Accessed: 8 May, 2015).

$<$ https://freedomhouse.org/report/freedom-net/2011/tunisia\#.VT_kar64ldg $>$.

—. 2013. "Freedom in the World: Algeria." Web. (Accessed: 8 May, 2015).

$<$ https://freedomhouse.org/report/freedom-world/2013/algeria\#.VUw4dr64ldg > .

—. 2014. "Freedom on the Net." Web. (Accessed: 8 May, 2015).

$<$ http://freedomhouse.org/report/freedom-net/freedom-net-2014\#.VT_jvb64ldi>.

. 2015. "Freedom in the World 2015." Web. (Accessed: 6 May, 2015).

$<$ https://freedomhouse.org/report/freedom-world/freedom-world-2015\#.VRTs1L

$641 \mathrm{dg}>$.

Gavrilets, Sergey and William Rice. 2009. "Genetic Models of Homosexuality:

Generating Testable Predictions.” Proceedings: Biological Sciences 273 (1605):

3031-3038.

Gettleman, Jeffrey. 2011. "Ugandan Who Spoke Up for Gays Is Beaten to Death.” The New York Times. 21 January, 2011. Web. (Accessed: 23 March, 2015). $<$ http://www.nytimes.com/2011/01/28/world/africa/28uganda.html?_r=0>.

Ghanmi, Lamine. 2010. "Morocco Resists Islamist Calls to Ban Elton John.” Reuters. 17 May, 2010. Web. (Accessed: 24 March, 2015). 
$<$ http://www.reuters.com/article/2010/05/17/us-eltonjohnidUSTRE64G5DV20100517>.

Goodman, Melvin. 2013. "The Blowback from Interventionism.” Consortium News. 27 April, 2013. Web. (Accessed: 23 March, 2015). $<$ https://consortiumnews.com/2013/04/27/the-blowback-from-interventionism/>. Gray, Stephen. 2012. “Casablanca: Gay Cruise Diverted.” Pink News. 2 July, 2012. Web. (Accessed: 25 March, 2015). $<$ http://www.pinknews.co.uk/2012/07/02/casablanca-gay-cruise-diverted/>. Grew, Tony. 2008. "Moroccan Newspaper Sued by Judges Over Gay Party Story.” Pink News. 26 March, 2008. Web. (Accessed: 25 March, 2008). $<$ http://www.pinknews.co.uk/2008/03/26/moroccan-newspaper-sued-by-judgesover-gay-party-story/>.

GSMA. 2014. “The Mobile Economy: Arab States 2014.” Groupe Speciale Mobile Association. Web. (Accessed: 7 May, 2015). $<$ http://arabstates.gsmamobileeconomy.com/GSMA_ME_Arab_States_2014.p df $>$.

Hafften, Marie. 2012. “Lesbians in Morocco: Should We Stay or Should We Go?” Global Post. 22 June, 2012. Web. (Accessed: 25 March, 2015). $<$ http://www.globalpost.com/dispatch/news/regions/africa/morocco/120621/ morocco-LGBT-gay-lesbian>. 
Harim, O. 2014. "Behind the Scenes With Algeria's First LGBT Magazine. The Observers. 12 March, 2014. Web. (Accessed: 26 March, 2015). $<$ http://observers.france24.com/content/20141203-algeria-first-lgbt-magazinegay>.

Harit, Fouad. 2013. “Maroc: Une Cyber-Campagne Contre L'Homophobie.” Afrik. 17 May, 2013. Web. (Accessed: 25 March, 2015). $<$ http://www.afrik.com/maroc-une-cyber-campagne-contre-l-homophobie $>$. Hassan Al-Ashraf, Rabat. 2009. "Gay Seminar Stirs Outrage in Morocco.” Al Arabiya News. 19 March, 2009. Web. (Accessed: 25 March, 2015). $<$ http://www.alarabiya.net/articles/2009/03/19/68776.html $>$.

Hayoun, Massoud. 2014a. "Morocco Convicts Six Men for Homosexuality." Al Jazeera America. 15 May, 2014. Web. (Accessed: 25 March, 2015). $<$ http://america.aljazeera.com/articles/2014/5/15/morocco-convicts6menforhomos exualityamidnationaldialogueongays.html $>$. . 2014b. “Moroccans' Gay Pride March Aims to Carve Out New Space From a Distance.” Al Jazeera America. 26 June, 2015. Web. (Accessed: 25 March, 2015). $<$ http://america.aljazeera.com/articles/2014/6/26/morocco-gay-pride0.html>. Helem. 2014. “About Us.” Web. (Accessed: 31 March, 2015). $<$ http://helem.net/?q=node/59>.

Hopkins, Curt. 2012. "Tunisia Promises to End Internet Censorship." The Daily Dot. 14 September, 2012. Web. (Accessed: 8 May, 2015). 
$<$ http://www.dailydot.com/news/tunisia-internet-censorship/>.

Hubbard, Ben. 2015. "Caning of Saudi Blogger is Delayed Amid Protests." The New York Times. 16 January, 2015. Web. (Accessed: 16 March, 2015).

<http://www.nytimes.com/2015/01/17/world/caning-of-saudi-blogger-is-delayedamid-protests.html?_r=0>.

Huffington Post. 2015. “Tunisia’s New Gay Rights Fight.” 13 March, 2015. Web.

(Accessed: 25 March, 2015).

$<$ http://www.huffingtonpost.com/2014/12/11/tunisia-gay-rights_n_6304872

.html>.

Hussain, Muzammil and Philip Howard. 2013. "What Best Explains Successful Protest Cascades? ICTs and the Fuzzy Causes of the Arab Spring." International Studies Review 15 (1): 48-66.

Index on Censorship. 2005. "Dossier on Morocco.” Index on Censorship 34 (3): 154-165. Inglehart, Ronald. 1977. The Silent Revolution: Changing Values and Political Styles Among Western Publics. Princeton, New Jersey: Princeton University Press.

- 1990. Culture Shift in Advanced Industrial Society. Princeton, New Jersey: Princeton University Press.

Internet World Stats. 2012a. "Morocco: Internet Usage and Marketing Report.” Web. (Accessed: 7 May, 2015). $<$ http://www.internetworldstats.com/af/ma.htm $>$. _. 2012b. “Algeria: Internet Usage and Marketing Report.” Web. (Accessed: 7 
May, 2015).

$<\mathrm{http}: / /$ www.internetworldstats.com/af/dz.htm $>$.

_. 2012c. "Tunisia: Internet Usage and Marketing Report.” Web. (Accessed: 7 May, 2015).

$<$ http://www.internetworldstats.com/af/tn.htm $>$.

—. 2014. "Internet Usage Statistics for Africa.” Web. (Accessed: 26 March, 2015).

$<\mathrm{http}: / /$ www.internetworldstats.com/stats $1 . h t m>$.

Iranian Queer Organization. 2015a. “Our Story.” Web. (Accessed: 28 March, 2015). $<$ http://www.irqo.org/english/?page_id=389>.

Itaborahy, Lucas and Jingshu Zhu. 2014. "State-Sponsored Homophobia: A World Survey of Laws: Criminalisation, Protection and Recognition of Same-Sex Love.” International Lesbian Gay Bisexual Trans and Intersex Association. Web. (Accessed: 20 March, 2015). $<$ http://old.ilga.org/Statehomophobia/ILGA_SSHR_2014_Eng.pdf $>$.

Iyengar, Shanto, Mark D. Peters, and Donald R. Kinder. 1993. "Experimental Demonstrations of the 'Not-So-Minimal' Consequences of Television News Program.” In Experimental Foundations of Political Science. Eds. Donald R Kinder and Thomas R. Palfrey. Michigan: The University of Michigan Press. Jasper, James. 1997. The Art of Moral Protest: Culture, Biography, and Creativity in Social Movements. Chicago: University of Chicago Press. 
Jean-Jacques, Sarah. 2014. “Gay \& Lesbian Mobilization in Algeria: The Emergence of a Movement.” Muftah. 15 December, 2014. Web. (Accessed: 25 March, 2014). $<$ http://muftah.org/gay-and-lesbian-mobilization-in-algeria/\#.VRM19b64ldg $>$. Joffé, George. 2014. "To Reign or Rule: Morocco’s Halting Road to Liberalization." World Politics Review. 22 April, 2014. Web. (Accessed: 7 May, 2015). $<$ http://www.worldpoliticsreview.com/articles/13719/to-reign-or-rule-morocco-shalting-road-to-liberalization>.

Karimi, Faith and Nick Thompson. 2014. 'Uganda's President Museveni Signs Controversial Anti-Gay Bill into Law.” CNN. 25 February, 2014. Web. (Accessed: 23 March, 2015).

<http://www.cnn.com/2014/02/24/world/africa/uganda-anti-gay-bill/>.

Kelmty - Associations Gays et Lesbiennes Tunisiens. 2015. Facebook. Web.

(Accessed: 24 March, 2015).

$<\mathrm{http}: / /$ www.facebook.com/kelmty $>$.

Kingsley, Patrick. 2014. “Egypt Jails Eight Men After 'Gay Marriage’ Ceremony on Nile.” The Guardian. 3 November, 2014. Web. (Accessed: 16 March, 2015). $<$ http://www.theguardian.com/world/2014/nov/03/egypt-jails-eight-men-gaymarriage-ceremony-nile $>$.

Kuhanen, Jan. 2008. "The Historiography of HIV and AIDS in Uganda." History in Africa 35: 301-325. 
Lee, Ian, and Sarah Sirgany. 2015. "Living in Fear: Egypt's Gay Community." CNN. 2 January, 2015. Web. (Accessed: 29 March, 2015). <http://www.cnn.com/2014/12/09/world/africa/egypts-gay-community-living-infear/>.

Lee, Timothy. 2013. "Here's How Iran Censors the Internet." The Washington Post. 15 August, 2013. Web. (Accessed: 28 March, 2015) $<$ http://www.washingtonpost.com/blogs/the-switch/wp/2013/08/15/heres-howiran-censors-the-internet/>.

Littauer, Dan. 2012. “Tunisian Human Rights Minister: No Free Speech for Gays.” Pink News. 6 February, 2012. Web. (Accessed: 24 March, 2015). $<$ http://www.pinknews.co.uk/2012/02/06/tunisian-human-rights-minister-no-freespeech-for-gays/>.

—. 2013. "Lebanon: Activists Protest Against Arrest and Abuse of Gays." Gay Star News. 1 May, 2013. Web. (Accessed: 27 March, 2015). $<$ http://www.gaystarnews.com/article/lebanon-activists-protest-against-arrest-andabuse-gays010513>.

—. 2014. "Lebanon Launches Police Raids Targeting Gay Men.” San Diego Gay \& Lesbian News. 15 August, 2014. Web. (Accessed: 27 March, 2015).

$<$ http://www.sdgln.com/news/2014/08/15/lebanon-launches-police-raids-targeting -gay-men\#sthash.GuXXx5su.dpbs>.

Lonkila, Markku. 2008. “The Internet and Anti-Military Activism in Russia.” Europe- 
Asia Studies 60 (7): 1125-1149.

Lucas, Michael. 2012. "Gays In The New, Complicated Tunisia.” Advocate. 4 December, 2012. Web. (Accessed: 25 March, 2015).

$<$ http://www.advocate.com/commentary/2012/12/04/gays-new-and-complicatedtunisia>.

Lust, Ellen. 2013. The Middle East. $13^{\text {th }}$ ed. Thousand Oaks, California: CQ Press.

Lutterback, Derek. 2013. "Tunisia After Ben Ali: Retooling the Tools of Oppression?" Norwegian Peacebuilding Resource Centre. Web. (Accessed: 6 May, 2015). $<$ http://www.peacebuilding.no/var/ezflow_site/storage/original/application/8a4a 0 1231edc1bc44e19af1182314d46.pdf>.

Lynch, Mark. 2012. The Arab Uprising: The Unfinished Revolutions of the New Middle East. $1^{\text {st }}$ ed. New York: Public Affairs.

Marks, Gary. 2009. "Modernization Theory and Changes Over Time in the Reproduction of Socioeconomic Inequalities in Australia.” Social Forces 88 (2): 917-944.

Marzouki, Nadia. 2010. "Algeria" in Women's Rights in the Middle East and North Africa: Progress Amid Resistance. Eds. Sanja Kelly and Julia Breslin. Lanham, MD: Rowman \& Littlefield Publishers.

Masriya, Aswat. 2014. "Egypt's Homosexuals Struggle for Freedom.” Egyptian Streets. 8 April, 2014. Web. (Accessed: 29 March, 2015). $<$ http://egyptianstreets.com/2014/04/08/egypts-homosexuals-struggle-for-freed $\mathrm{om} />$. 
McCarthy, John and Mayer Zald. 1977. "Resource Mobilization and Social Movements: A Partial Theory." American Journal of Sociology 82 (6): 1212-1241.

McCarthy, Justin. 2014. "Nearly 3 in 10 Worldwide See Their Areas as Good for Gays." Gallup. 27 August, 2014. Web. (Accessed: 20 March, 2015). $<$ http://www.gallup.com/poll/175520/nearly-worldwide-areas-good-gays.aspx>.

McCombs, Maxwell. 2004. Setting the Agenda: The Mass Media and Public Opinion. Cambridge: Polity Press.

Mekhennet, Souad, and Maïa de la Baume. 2011. "Moderate Islamist Party Winning Morocco Election.” New York Times. 26 November, 2011. Web. (Accessed: 7 May, 2015).

$<$ http://www.nytimes.com/2011/11/27/world/africa/moderate-islamist-partywinning-morocco-election.html?_r $=0>$.

Melucci, Alberto. 1996. Challenging Codes: Collective Action in the Information Age. New York: Cambridge University Press.

Merrill, Jamie. 2015. “Gay Rights Activists Defy Ugandan Laws by Publishing New LGBTI Magazine.” 4 January, 2010. Web. (Accessed: 23 March, 2015). $<$ http://www.independent.co.uk/news/media/press/gay-rights-activists-defyugandan-laws-by-publishing-new-lgbti-magazine-9955950.html>.

Miles, Matthew. 2013. “The Bully Pulpit and Media Coverage: Power Without Persuasion.” The International Journal of Press/Politics 19 (1): 66-84. 
Morgan, Joe. 2015. "Swedish Gay Man Jailed in Tunisia for 'Homosexual Acts'.” Gay Star News. 8 February, 2015. Web. (Accessed: 25 March, 2015). $<$ http://www.gaystarnews.com/article/swedish-gay-man-jailed-tunisia-homosexu al-acts080215>.

Muhumuza, Rodney. 2014. "Uganda's Gay Community Celebrates Pride After AntiLGBT Law Invalidated.” The Huffington Post. 11 August, 2014. Web. (Accessed: 23 March, 2013). $<$ http://www.huffingtonpost.com/2014/08/11/uganda-gay-pride-parade_n_5668148.html>.

Mumtaz, Ghina, Nahla Hilmi, Willi McFarland, Rachel Kaplan, Francisca Ayodeji, Iris Semini, Gabriele Riedner, Oussama Tawil, David Wilson, and Laith Abu-Raddad. 2011. “Are HIV Epidemics Among Men Who Have Sex with Men Emerging in the Middle East and North Africa?: A Systematic Review and Data Synthesis."PLoS Medicine 8 (8): 1-15.

Murphy, Timothy. 2005. “The Search For The Gay Gene.' BMJ: British Medical Journal 330 (7498): 1033.

Naar, Ismaeel. 2013. "Shifting Gear: Saudi Women Defy Driving Ban.” Al Jazeera. 27 October, 2013. Web. (Accessed: 27 March, 2015). $<$ http://www.aljazeera.com/indepth/features/2013/10/shifting-gear-saudi-womendefy-driving-ban-20131027132853713829.html>.

Oldershausen, Sasha. 2012. "Iran's Sex-Change Operations Provided Nearly Free-Of- 
Cost.” 4 June, 2012. Web. (Accessed: 20 March, 2015).

$<$ http://www.huffingtonpost.com/2012/06/04/iran-sex-changeoperation_n_1568604.html>.

Online Maps. 2012. “Africa Population Density.” 23 September, 2013. Web. (Accessed: 7 May, 2015). $<$ http://onlinemaps.blogspot.com/2012/09/africa-population-density.html $>$.

OpenNet Initiative. 2009a. “Algeria.” Web. (Accessed: 8 May, 2015).

$<$ https://opennet.net/research/profiles/algeria $>$.

—. 2009b. "Morocco." Web. (Accessed: 8 May, 2015).

$<$ https://opennet.net/research/profiles/morocco $>$.

O’Riordan, Kate. 2012. “The Life of the Gay Gene: From Hypothetical Genetic Marker to Social Reality." The Journal of Sex Research 49 (4): 362-368.

Overseas Security Advisory Council. 2014. "Morocco 2014 Crime and Safety Report." United States. Department of State. Bureau of Diplomatic Security. 10 February, 2014. Web. (Accessed: 25 March, 2015).

$<$ https://www.osac.gov/Pages/ContentReportDetails.aspx?cid=15123>.

Palau, Anna and Ferran Davesa. 2013. "The Impact of Media Coverage of Corruption on Spanish Public Opinion.” Revista Española de Investigaciones Sociológicas 144: 97-124.

Penketh, Anne. 2008. "Brutal land where homosexuality is punishable by death." The Independent. 6 March, 2008. Web. (Accessed: 26 March, 2014). 
$<$ http://www.independent.co.uk/news/world/middle-east/brutal-landwhere-homosexuality-is-punishable-by-death-792057.html $>$.

Pew Research Center. 2013. “The Global Divide on Homosexuality: Greater Acceptance in More Secular and Affluent Countries.” Pew Research Center. 4 June, 2013. Web. (Accessed: 20 March, 2015). <http://www.pewglobal.org/2013/06/04/the-global-divide-on-homosexuality/>.

Pfeiffer, Tom and Zakia Abdennebi. 2008. "Liberals and Islamists Clash Over Morocco 'Gay Wedding'.” Reuters. 13 March, 2008. Web. (Accessed: 25 March, 2015). $<$ http://uk.reuters.com/article/2008/03/13/uk-rights-moroccoidUKL0581448520080313>.

Pink News. 2007. "Home Office Loses Gay Algerian Deportation Case.” 24 October, 2007. Web. (Accessed: 25 March, 2015). $<$ http://www.pinknews.co.uk/2007/10/24/home-office-loses-gay-algeriandeportation-case/>.

Polity IV. 2010. "Polity IV Country Report 2010: Algeria.” Web. (Accessed: 8 May, 2015). $<$ http://www.systemicpeace.org/polity/Algeria2010.pdf $>$. . 2014a. “Authority Trends, 1962-2013: Algeria.” Web. (Accessed: 26 March, 2015). $<$ http://www.systemicpeace.org/polity/alg2.htm>. 
—. 2014b. “Authority Trends, 1956-2013: Morocco.” Web. (Accessed: 26 March, 2015).

$<$ http://www.systemicpeace.org/polity/mor2.htm $>$.

—. 2014c. "Authority Trends, 1959-2013: Tunisia.” Web. (Accessed: 26 March, 2015).

$<$ http://www.systemicpeace.org/polity/tun2.htm>.

Putnam, Robert. 1988. “Diplomacy and Domestic Politics: The Logic of Two-Level Games.” International Organization 42 (3): 427-460.

Ramdani, Nahila. 2011. “Algeria Tried to Block Internet and Facebook as Protest Mounted.” 12 February, 2011. Web. (Accessed: 24 March, 2015). $<$ http://www.telegraph.co.uk/news/worldnews/africaandindianocean/algeria/ 8320772/Algeria-tried-to-block-internet-and-Facebook-as-protest-mounted.html>.

Rawlinson, Kevin. 2014. "British Man Jailed for Four Months in Morocco 'For Being Gays'.” The Guardian. 5 October, 2014. Web. (Accessed: 25 March, 2015). $<$ http://www.theguardian.com/world/2014/oct/06/british-man-ray-cole-70-jailedfour-months-morocco-gay>.

Reger, Jo and Kimberly Dugan. 2001. "Exploring Social Movement Theories Through an Interactive Exercise." Teaching Sociology 29 (3): 332-342.

Rhanem, Karima. 2006. "Sex Scandal: Gay Porn Network Sentenced to 30 Years in Prison.” Morocco Times. 6 March, 2006. Web. (Accessed: 25 March, 2015). 
$<$ http://karimarhanem.skyrock.com/2167919511-Sex-Scandal-Gay-porn-networksentenced-to-30-years-in-prison.html> .

Roberts, Matthew. 1995. "The Emergence of Gay Identity and Social Movements in Developing Countries: The AIDs Crisis as Catalyst." Alternatives: Global, Local, Political 20 (2): 243-248.

Roberts, Scott. 2015. "Morocco Jails 2 Men for Committing a 'Deviant Sexual Act'." Pink News. 5 March, 2015. Web. (Accessed: 25 March, 2015). $<$ http://www.pinknews.co.uk/2015/03/05/morocco-jails-2-men-for-committing-adeviant-sexual-act/>.

Salhi, Zahia. 2010. “Algerian Women, Citizenship, and the 'Family Code'.” Gender \& Development 11 (3): 27-35.

Schedler, Andreas. 2002. “The Menu of Manipulation.” Journal of Democracy 13 (2): 36-50.

Schweiger, Laura. 2011. "EU Asylum Policy for Gays and Lesbians Criticized by LGBT Groups.” Deutsche Welle. 19 May, 2011. Web. (Accessed: 25 March, 2015). $<$ http://www.dw.de/eu-asylum-policy-for-gays-and-lesbians-criticized-by-lgbtgroups/a-15089739>.

Sheils, Conor. 2014. "Egypt's Gay Activists are Ready to Fightback.” Cairo Scene. 28 September, 2014. Web. (Accessed: 29 March, 2015). $<$ http://www.cairoscene.com/ViewArticle.aspx?AId=14210-Egypt's-Gay-Activist s-Are-Ready-To-Fightback>. 
Schumpeter, Joseph. 1950. Capitalism, Socialism, and Democracy. New York: Harper.

Sidiguitiebe, Christophe. 2014. "L'homosexualité au Maroc Devient-elle Moins Tabou?"

Telquel. 16 May, 2014. Web. (Accessed: 25 March, 2015).

$<$ http://telquel.ma/2014/05/16/lhomosexualite-au-maroc-devient-elle-moinstabou_136020>.

Sieczkowski, Cavan. 2014. "Sochi Mayor Says There Are No Gay People In His

City.” The Huffington Post. 27 January, 2014. Web. (Accessed: 26

March, 2014).

$<$ http://www.huffingtonpost.com/2014/01/27/sochi-mayor-no-gay-

people_n_4673232.html>.

Similar Web. 2014. "Website Ranking: Top 50 Sites in Tunisia for All Categories." Web.

(Accessed: 8 May, 2015).

$<$ http://www.similarweb.com/country/tunisia $>$.

Slimane. 2010. "Being Gay in Algeria Today." Global Gayz. 13 January, 2013. Web.

(Accessed: 25 March, 2015).

$<$ http://www.globalgayz.com/being-gay-in-algeria-today/391/ >.

Smith, David. 2010. "Gay Magazine Launched in Morocco.” The Guardian. 20 May, 2010. Web. (Accessed: 24 March, 2015).

$<$ http://www.theguardian.com/world/2010/may/20/gay-magazine-launchmorocco-rights $>$. 
Stern, Jason. 2014. "Saudi Arabia Steps Up Censorship, Snaring Activists." The

Huffington Post. 27 May, 2014. Web. (Accessed: 27 March, 2015).

$<$ http://www.huffingtonpost.com/committee-to-protect-journalists/saudi-arabiasteps-up-cen_b_5398145.html>.

Sufian, Sandy. 2004. "HIV/AIDs in the Middle East and North Africa: A Primer." Middle East Report (233): 6-9.

Tait, Robert. 2005. “A Fatwa for Freedom.” The Guardian. 27 July, 2015. Web. (Accessed: 28 March, 2015). $<$ http://www.theguardian.com/world/2005/jul/27/gayrights.iran>.

Tammen, Ronald, Jacek Kugler, Douglas Lemke, Allan Stam III, Carole Alsharabati, Mark Abdollahian, Brian Efird, and A.F.K. Organski. 2000. Power Transitions: Strategies for the 21st Century. Washington, D.C.: CQ Press.

Tarrow, Sidney. 2011. Power in Movement: Social Movements and Contentious Politics. New York, N.Y.: Cambridge University Press.

TGEU. 2012. "816 Reported Cases of Murdered Trans People Between January 2008 and December 2011.” Transgender Europe. Web. (Accessed: 20 March, 2015). $<$ http://www.transrespect-transphobia.org/uploads/images/maps/TvT-TMMMap2008-11-en2.png>.

_. 2014a. "Legal and Social Mapping - World \#1.” Transgender Europe. Web. (Accessed: 20 March, 2015). $<$ http://www.transrespect-transphobia.org/uploads/downloads/Legal-Social- 
Mapping2014/web_tvt_mapping_1_EN.pdf $>$.

.2014b. “Legal and Social Mapping - World \#2." Transgender Europe. Web.

(Accessed: 20 March, 2015).

$<$ http://www.transrespect-transphobia.org/uploads/downloads/Legal-SocialMapping2014/web_tvt_mapping_2_EN.pdf $>$.

Tilly, Charles. 2004. Social Movements, 1768-2004. Boulder: Paradigm Publishers. Torbey, Carine. 2005. “Lebanon's Gays Struggle With Law.” BBC News. 29 August, 2005. Web. (Accessed: 6 May, 2015).

$<$ http://news.bbc.co.uk/2/hi/middle_east/4154664.stm>.

Tutton, Mark. 2010. “Algerian Transsexual's Memoirs Reveal Life of Discrimination.”

CNN. 9 July, 2010. Web. (Accessed: 25 March, 2015).

$<$ http://www.cnn.com/2010/WORLD/meast/07/09/randa.algeria.transsexu al.lebanon/>.

UNHCR. 2007. “Algeria: Treatment of Homosexuals by Society and Government Authorities; Protection Available Including Recourse to the Law for Homosexuals Who Have Been Subject to Ill-Treatment (2005-2007).” United Nations. United Nations High Commissioner for Refugees. 30 July, 2007. Web. (Accessed: 25 March, 2015).

$<$ http://www.refworld.org/cgi-bin/texis/vtx/rwmain?page=country\&category $=\&$ publisher $=I R B C \&$ type $=\&$ coi $=D Z A \&$ rid $=\&$ docid $=474 \mathrm{e} 895 \mathrm{c} 1 \mathrm{e} \&$ skip $=0>$. 
U.S. Department of State. 2013. "Country Reports on Human Rights Practices for 2013: Morocco." United States. Department of State. Bureau of Democracy, Human Rights and Labor. Web. (Accessed: 25 March, 2015). $<\mathrm{http}: / /$ www.state.gov/j/drl/rls/hrrpt/humanrightsreport/index.htm? year $=2013 \& \mathrm{dlid}=220369>$.

Watan, Cherfaoui. 2004. "Bouteflika Favorable à la Révision du Code de la Famille." Algerie-DZ. 11 October, 2004. Web. (Accessed: 24 March, 2015). $<$ http://www.algerie-dz.com/article1172.html $>$.

Whitaker, Brian. 2006. Unspeakable Love: Gay and Lesbian Life in the Middle East. Los Angeles, California: University of California Press.

Wong, Curtis. 2014. 'Ricky Martin Changes 'She' To 'He' During Performance Of 'She's All I Ever Had' In Morocco.” The Huffington Post. 16 June, 2014. Web. (Accessed: 24 March, 2015). $<$ http://www.huffingtonpost.com/2014/06/16/ricky-martin-pronounsong_n_5499402.html>.

World Values Survey. 2010-2014. “Online Data Analysis.” Web. (Accessed: 16 March, 2014). $<$ http://www.worldvaluessurvey.org/WVSOnline.jsp>.

Yes People! We Do Exist! 2015. Facebook. Web. (Accessed: 28 March, 2015). $<$ https://www.facebook.com/IranianLGBTcommunity $>$. 
Zarindast, Karen, and Saeedeh Hashemi. 2012. “Iran's Health Insurers to Pay for Sex Change Operations.” BBC News. 29 May, 2012. Web. (Accessed: 28 March, 2015) $<$ http://www.bbc.com/news/world-middle-east-18258276>. 